\title{
Waste Package Degradation Expert Elicitation Panel: Input on the Corrosion of CRM Alloy C-22
}

\author{
Joseph C. Farmer
}

March 14, 1998

This is an informal report intended primarily for internal or limited external distribution. The opinions and conclusions stated are those of the author and may or may not be those of the Laboratory.

Work performed under the auspices of the U.S. Department of Energy by the Lawrence Livermore National Laboratory under Contract W-7405-Eng-48. 


\section{DISCLAIMER}

This document was prepared as an account of work sponsored by an agency of the United States Government. Neither the United States Government nor the University of California nor any of their employees, makes any warranty, express or implied, or assumes any legal liability or responsibility for the accuracy, completeness, or usefulness of any information, apparatus, product, or process disclosed, or represents that its use would not infringe privately owned rights. Reference herein to any specific commercial product, process, or service by trade name, trademark, manufacturer, or otherwise, does not necessarily constitute or imply its endorsement, recommendation, or favoring by the United States Government or the University of California. The views and opinions of authors expressed herein do not necessarily state or reflect those of the United States Government or the University of California, and shall not be used for advertising or product endorsement purposes.

This report has been reproduced directly from the best available copy.

Available to DOE and DOE contractors from the Office of Scientific and Technical Information

P.O. Box 62, Oak Ridge, TN 37831

Prices available from (615) 576-8401, FTS 626-8401

Available to the public from the

National Technical Information Service

U.S. Department of Commerce

5285 Port Royal Rd.,

Springfield, VA 22161 


\title{
WASTE PACKAGE DEGRADATION EXPERT ELICITATION PANEL: INPUT ON THE CORROSION OF CRM ALLOY C-22
}

\author{
Joseph C. Farmer, Ph.D. \\ University of California, Lawrence Livermore National Laboratory \\ 7000 East Avenue or P.O. Box 808, Mail Stop L-352 \\ Livermore, California 94550 \\ Telephone 510-423-6574 \\ Fax 510-423-2086 \\ E-mail: farmer4@llnl.gov \\ Secretary (Nan Poggio) 510-422-9279
}

March 14, 1998 (Rev. 7); February 26, 1998 (Rev. 0)

\section{ANTICIPATED ENVIRONMENTS}

The overall electrolyte concentration in the NFE environment is expected to be somewhere between $1 \mathrm{X}$ and saturated J-13 well water. This covers more than three orders-of-magnitude in chloride anion concentration. The pH of this solution is expected to be somewhere between 5 and 10. Exposed patches of the CRM could see this environment.

The $\mathrm{pH}$ in the crevice can be acidified due to the hydrolysis of dissolved polyvalent cations, such as $\mathrm{Fe}^{2+}$. As discussed by Oldfield and Sutton, metal ions produced by anodic dissolution are assumed to undergo the following hydrolysis reactions [J. W. Oldfield, W. H. Sutton, "Crevice Corrosion of Stainless Steels: I. A Mathematical Model," British Corrosion Journal, Vol. 13, No. 1, 1978, pp. 13-22]:

$$
\begin{aligned}
& \mathrm{Fe}^{2+}+\mathrm{H}_{2} \mathrm{O} \underset{K_{3,1}}{\longleftrightarrow} \mathrm{Fe}(\mathrm{OH})^{+}+\mathrm{H}^{+} \\
& \mathrm{Fe}^{3+}+\mathrm{H}_{2} \mathrm{O} \underset{\mathrm{K}_{4,1}}{\longrightarrow} \mathrm{Fe}(\mathrm{OH})^{2+}+\mathrm{H}^{+} \\
& \mathrm{Ni}^{2+}+\mathrm{H}_{2} \mathrm{O} \underset{K_{\mathrm{s}, 1}}{\longrightarrow} \mathrm{Ni}(\mathrm{OH})^{+}+\mathrm{H}^{+} \\
& \mathrm{Cr}^{3+}+\mathrm{H}_{2} \mathrm{O} \underset{\mathrm{K}_{1,1}}{\longrightarrow} \mathrm{Cr}(\mathrm{OH})^{2+}+\mathrm{H}^{+} \\
& \mathrm{Cr}(\mathrm{OH})^{2+}+\mathrm{H}_{2} \mathrm{O} \underset{K_{1,2}}{\longrightarrow} \mathrm{Cr}(\mathrm{OH})_{2}^{+}+H^{+}
\end{aligned}
$$

These reactions have also been considered in a crevice corrosion model published by the NRC [J. C. Walton, S. K. Kalandros, "TWITCH - A Model for Transient Diffusion, Electromigration, and Chemical Reaction in One Dimension," Center for Nuclear Waste Regulatory Analyses, San Antonio, TX, CNWRA 92-019, 1992]. The range of $\mathrm{pH}$ expected under a worst-case scenario (no precipitation of $\mathrm{FeCO}_{3}$; no leakage of dissolved metal or acid out of the crevice; no pH buffers; etc.) is illustrated by the data of Jones et al., as shown in Table 1 [D. A. Jones, B. E. Wilde, "Galvanic Reactions During Localized Corrosion on Stainless Steel," Corrosion Science, Vol. 18, 1978, pp. 631-643]. 
Table 1. Suppression of $\mathrm{pH}$ by Hydrolysis Reactions in $\mathrm{FeCl}_{2}, \mathrm{NiCl}_{2}$, and $\mathrm{CrCl}_{3}\left(25^{\circ} \mathrm{C}\right)$.

\begin{tabular}{|c|c|c|c|}
\hline Salt & $1 \mathrm{~N}$ & $3 \mathrm{~N}$ & Saturated \\
\hline $\mathrm{FeCl}_{2}$ & 2.1 & 0.8 & 0.2 \\
\hline $\mathrm{NiCl}_{2}$ & 3.0 & 2.7 & 2.7 \\
\hline $\mathrm{CrCl}_{3}$ & 1.1 & -0.3 & -1.4 \\
\hline
\end{tabular}

The lowest possible $\mathrm{pH}$ values expected with $\mathrm{FeCl}_{2}$ solutions at $25^{\circ} \mathrm{C}$ is 0.2 . The $\mathrm{pH}$ levels measured in $\mathrm{FeCl}_{3}$ solutions by Francis Wang are shown in Table 2 .

Table 2. Suppression of pH by Hydrolysis Reactions in $\mathrm{FeCl}_{3}$ Solutions $\left(25^{\circ} \mathrm{C}\right)$.

\begin{tabular}{|l|l|}
\hline $\mathrm{FeCl}_{3}$ (wt. \%) & $\mathrm{pH}$ \\
\hline 1 & 1.92 \\
\hline 2 & 1.83 \\
\hline 3 & 1.71 \\
\hline 4 & 1.63 \\
\hline 10 & 0.70 \\
\hline
\end{tabular}

More realistic estimates must include transport of $\mathrm{Fe}^{2+}$ and other species out of the crevice, limitations on the rate of $\mathrm{Cl}^{-}$transport into the crevice, $\mathrm{pH}$ buffer effects due to other ion, and precipitation of hydrolyzable $\mathrm{Fe}^{2+}$ by carbonate. Such effects will tend to make the $\mathrm{pH}$ higher than these extreme values based upon thermodynamic equilibrium. A transport model for crevice corrosion has been developed by two of members of this Expert Elicitation Panel and was used to predict a pH of roughly 2.8-3.2 during the attack of Alloy 625 [J. C. Farmer, R. D. McCright, "Crevice Corrosion and Pitting of High-Level Waste Containers: Integration of Deterministic and Probabilistic Models," Paper No. 160, Annual Meeting of the National Association of Corrosion Engineers (NACE), Corrosion 98, San Diego, CA March 22-27, 1998].

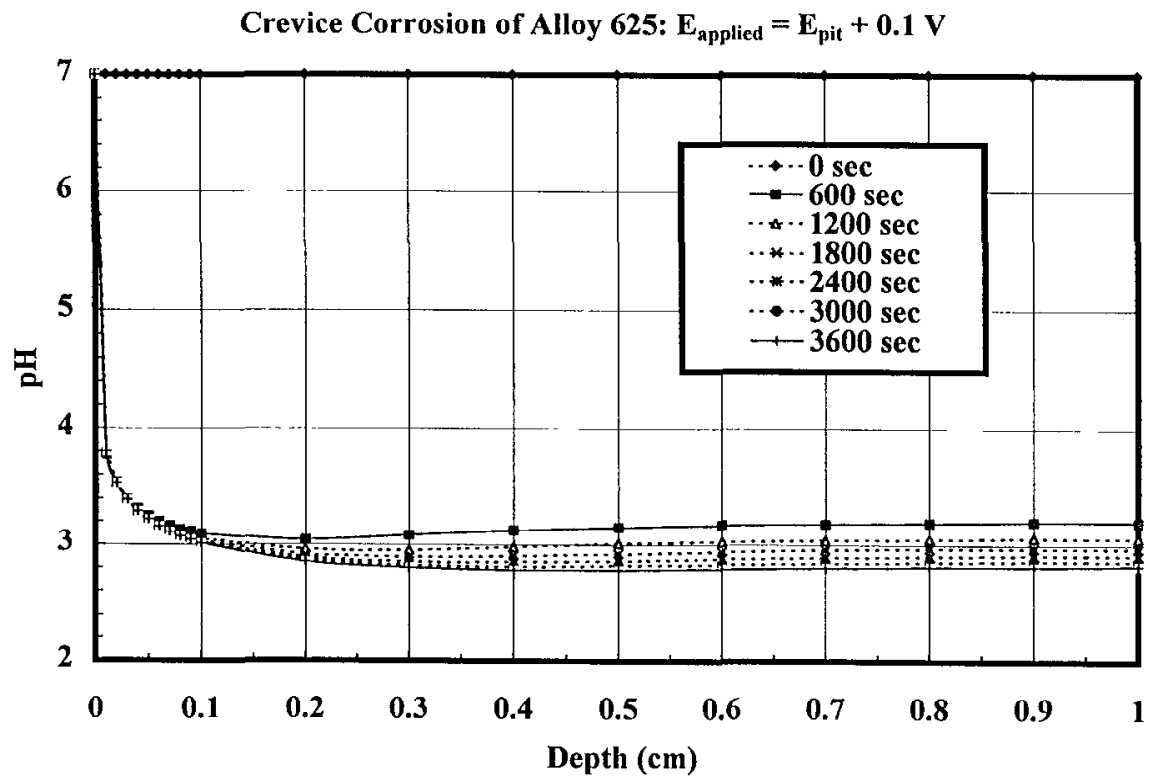

Figure 1. Prediction of transport-limited pH suppresion in crevice during attack of Alloy 625. The potential assumed as a boundary condition at the crevice mouth (applied potential) was fixed at a level $100 \mathrm{mV}$ more anodic that the critical pitting potential of Alloy 625. 
As pointed out by Dr. Kevin McCoy, the measured pH in active, artificial crevices is: 3.3 to 4.7 if the crevice is formed with carbon steel; 2.4 to 4.0 if the crevice is formed with a Fe-Cr alloy, and $\leq 2.3$ if the crevice is formed with a stainless stcel [J. K. McCoy, "Limits on $\mathrm{pH}$ for Waste Package Crevice Corrosion," Private Communication, August 11, 1997; Z. Szklarski-Smialowska, "Pitting Corrosion of Metals," NACE, Houston, TX, 1986, p. 311-312]. During the Appendix 7 Meeting, the range of expected values given by the NRC Center are:

A. NFE $5<\mathrm{pH}<10$

B. Crevice - Before Localized Corrosion of CRM: $3<\mathrm{pH}<5$. Likely case, since this will occur near Ecorr of A516. Due to hydrolysis of Fe alone. Depends upon transport and crevice geometry.

C. Crevice - After Localized Corrosion of CRM: $-1<\mathrm{pH}<3$. Requires potential above repassivation potential, and considered very unlikely. Due to hydrolysis of other dissolved metals, such as $\mathrm{Cr}$ and Mo. Depends on transport and crevice geometry.

It is believed that the electrochemical potential at the mouth of the crevice will be somewhere between the mixed potential of A516 Gr 55 and Alloy C-22, in either concentrated J-13 or concentrated (10 wt. \% $\mathrm{FeCl}_{3}$ ). See Table 3.

Table 3. Expected Electrochemical Potentials in Repository-Based on Measurements of A516 Gr. 12 (CAM) and Alloy C-22 (CRM).

\begin{tabular}{|l|c|c|c|c|c|}
\hline Case & A & B & C & D & E \\
\hline $\mathrm{T}\left({ }^{\circ} \mathrm{C}\right)$ & 90 & 90 & 90 & 90 & 90 \\
\hline $\mathrm{NaCl}$ (wt. \%) & 10 & 1 & 0 & 0 & 5 \\
\hline $\mathrm{FeCl}_{3}$ (wt. \%) & 0 & 0 & 0.6 & 3.1 & 0 \\
\hline $\mathrm{pH}$ & 6.8 & 2.7 & 2.14 & 1.72 & 2.7 \\
\hline Radiolysis & No & No & No & No & No \\
\hline Deaerated & No & Yes & Yes & Yes & No \\
\hline $\mathrm{E}_{\text {corr }}$ (mV vs. SHE): A516 Gr 55 & & & & & -520 \\
\hline $\mathrm{E}_{\text {corr }}(\mathrm{mV}$ vs. SHE): C-22 & -24 & -29 & +661 & +714 & \\
\hline $\mathrm{E}_{\text {pit }}$ (mV vs. SHE): C-22 & +442 & +758 & +905 & +889 & $>+730$ \\
\hline $\mathrm{E}_{\text {pass }}$ (mV vs. SHE): C-22 & +550 & +793 & +857 & +896 & $>+730$ \\
\hline Above Threshold Potential & No & No & No & No & No \\
\hline
\end{tabular}

In the absence of $\mathrm{FeCl}_{3}$, which is a product of the $\mathrm{CAM}$ corrosion, the greatest mixed potential expected is somewhere between -520 and $-29 \mathrm{mV}$ vs. SHE at $90^{\circ} \mathrm{C}$. With $\mathrm{FeCl}_{3}$ at $10 \mathrm{wt} \%$, potentials as high as $+714 \mathrm{mV}$ vs. SHE have been observed. Since the observed mixed potential never exceeded the pitting potential or the repassivation potential, localized attack is not be expected. This interpretation is consistent with the interpretation of Cragnolino [G. A. Cragnolino, DOE/NRC Appendix 7 Meeting, Livermore, CA, February, 1998]. These observations do not account for the effects of gamma radiolysis and other effects.

From transport modeling of corrosion in the CAM-CRM crevice, it is known that the electrochemical potential inside the crevice is less anodic (less severe) than the potential established or applied at the mouth of the crevice [J. C. Farmer, R. D. McCright, "Crevice Corrosion and Pitting of High-Level Waste Containers: Integration of Deterministic and Probabilistic Models," Paper No. 160, Annual Meeting of the National Association of Corrosion Engineers (NACE), Corrosion 98, San Diego, CA March 22-27, 
1998]. This is due to ohmic drop along the length of the crevice. Consequently, any estimate of corrosion rate based on the electrochemical potential at the crevice mouth, coupled with the assumption of suppressed $\mathrm{pH}$ and elevated chloride inside the crevice, should be conservative.

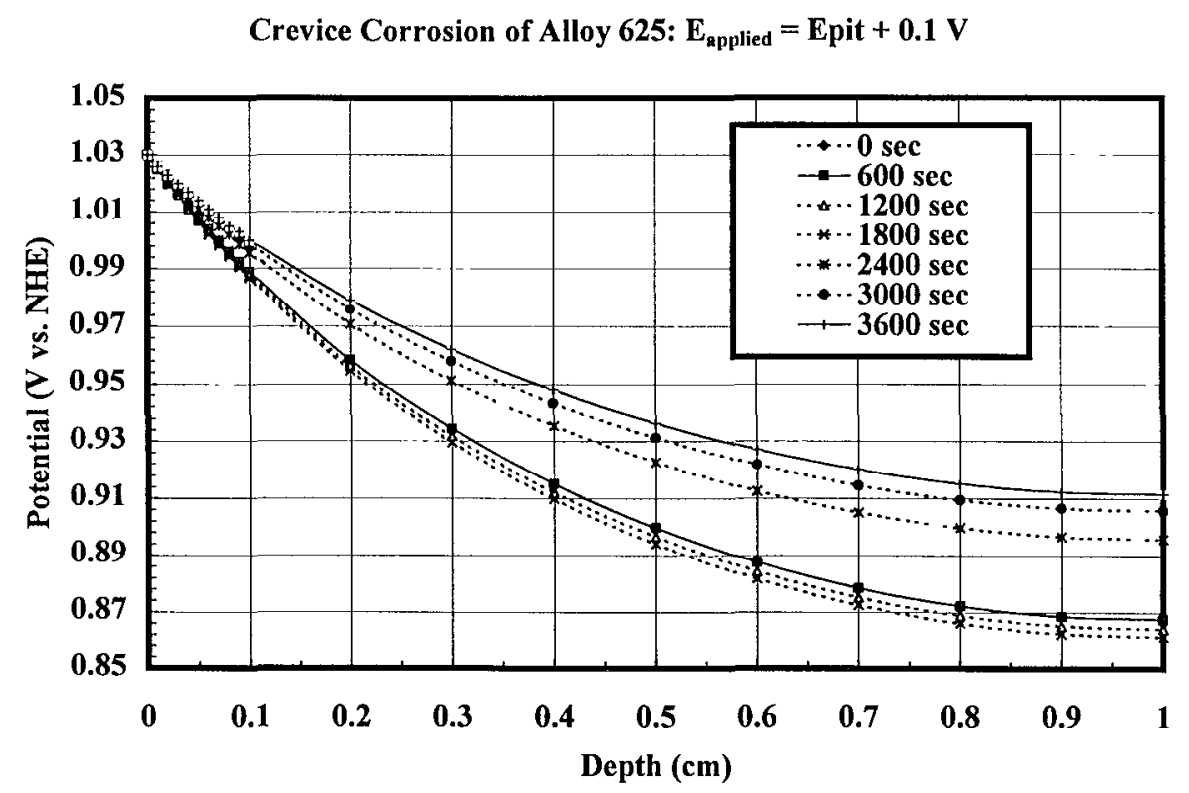

Figure 2. Electrochemical potential inside crevice is less severe than that applied in the mouth. The potential assumed as a boundary condition at the crevice mouth (applied potential) was fixed at a level $100 \mathrm{mV}$ more anodic that the critical pitting potential of Alloy 625. Corresponds to Figure 1.

In summary, the environmental conditions determined to be of greatest interest by consensus of the entire Expert Elicitation Pancl are summarized below:
A. Temperature: $\mathrm{T}=25,50$, and $100^{\circ} \mathrm{C}$
B. Acidity: $\mathrm{pH}=2.5 \& 3-10$
C. Electrochemical Potential: $E=340 \& 640 \mathrm{mV}$ vs. SHE

\section{PASSIVE CORROSION RATES OF ALLOY C-22 IN RELEVANT ENVIRONMENTS}

\section{Questions:}

1) What is the general corrosion (or passive dissolution) rate of the $\mathrm{C}-22$ inner barrier in humidair conditions (i.e., without drips) at 25,50 and $100^{\circ} \mathrm{C}$ ?

It is assumed that without drips, the inner barrier is exposed to mostly benign conditions in the potential repository.

The corrosion rates given should specify, as a minimum, the 0th and 100th percentile values along with the median, 5 th percentile and 95 th percentile values.

2) What is the general corrosion (or passive dissolution) rate of the inner barrier under dripping conditions? 
Please consider the combination of temperature, $\mathrm{pH} 7-10$, and concentrated chemistry conditions represented by $1000 \mathrm{X} \mathrm{J}-13$ and fully saturated $\mathrm{J}-13$ :

The corrosion rates given should specify, as a minimum, the 0th and 100th percentile values along with the median, 5th percentile and 95th percentile values.

\section{Response:}

Reasonable values for the penetration rate of Alloy C-22 due to dissolution through the passive film appear to be between 0.009 microns per year in a simulated, acidified, concentrated, J-13 well water, and 13 microns per year in a simulated crevice solution. Passive corrosion is consistent with opinions voiced by representative of the NRC. They state that no significant localized corrosion (localized penetration of the passive film) occurs at potentials well below the repassivation potential, $\mathrm{E}_{\text {pass. }}$ In the absence of radiolysis, the measured corrosion potential (mixed potential), $\mathrm{E}_{\text {corr, }}$ in such environments appears to be well below $\mathrm{E}_{\text {pass. }}$. This is a general view held by other investigators in the field of corrosion science. The observed penetration rates for Alloy C-22 in relevant environments are summarized in Figure 3, and are indicative of passive corrosion.

\section{Range of Observed Penetration Rates for Alloy C-22}

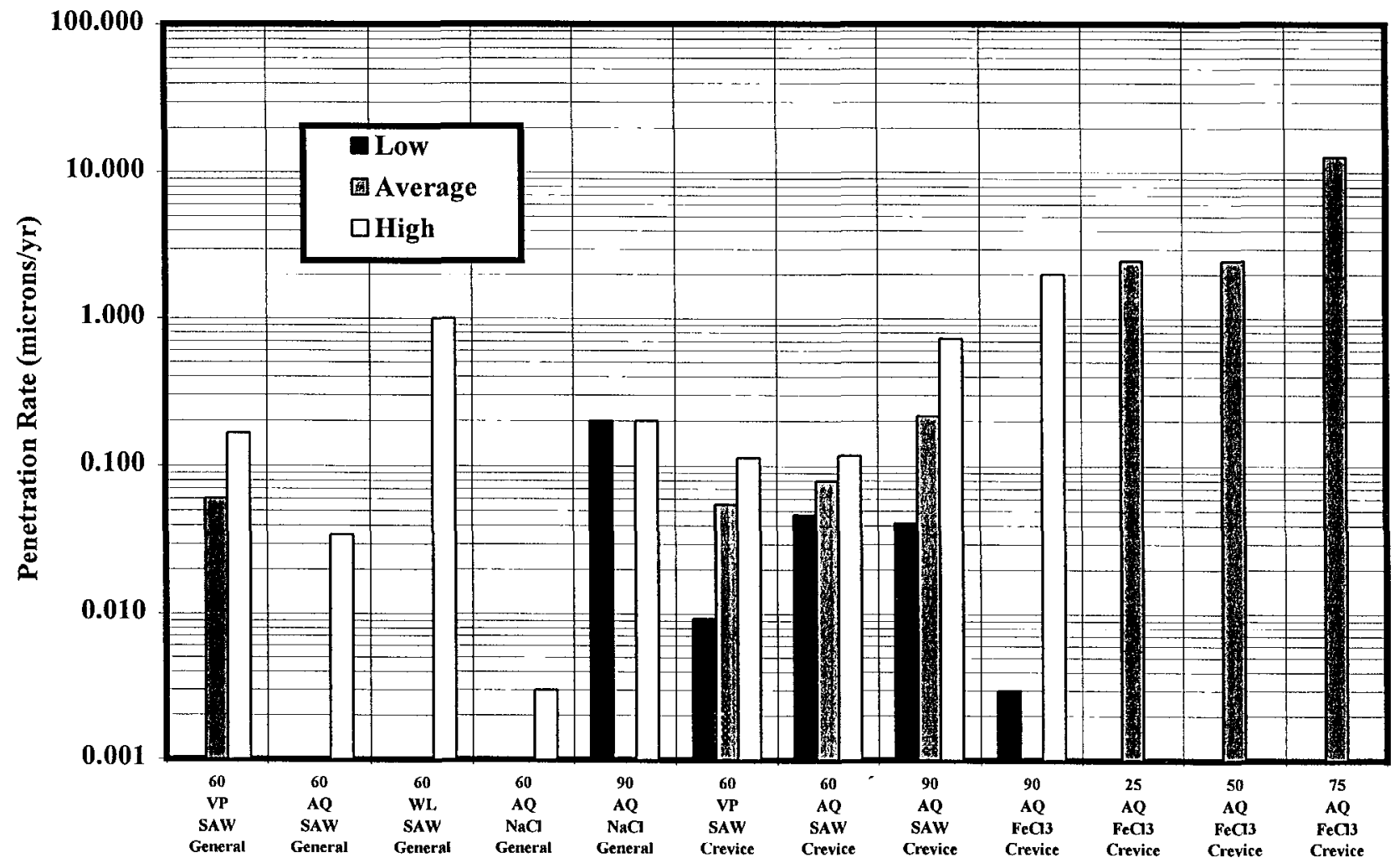

Figure 3. Observed Passive Corrosion Rates for Alloy C-22: Measured Weight Loss of Samples Exposed in Long Term Corrosion Test Facility (LTCTF); Corrosion Current Measurements at Open Circuit Potential (Roy, LLNL); and Measured Weight Loss of Samples Exposed to Simulated Crevice Solutions (Asphahani, Hanes International).

These observations are well represented by the regression equation (correlation) given to the EEP earlier. Data from the LTCTF was combined with the rates calculated from Roy's linear sweep polarization measurements, as well as the rates published by Asphahani. The combined data set was then used as the 
basis of an overall correlation of penetration rates with temperature, $\mathrm{pH}$, equivalent $\mathrm{NaCl}$ concentration, and $\mathrm{FeCl}_{3}$ [J. C. Farmer et al., "Development of Models for High-Level Waste Containers," Proc. $6{ }^{\text {th }}$ Intl. Conf. On Nuclear Engineering, ICONE-6, May 10-15, 1998, San Diego, California, ASME, 1998, 13 p.]. The following linear equation was found to be adequate for the correlation of Alloy $\mathrm{C}-22$ penetration rates:

$\ln \left(\frac{\Delta p}{\Delta t}\right)=b_{0}+b_{1}\left(\frac{1000}{T+273}\right)+b_{2}(p H)+b_{3}\left(C_{N a C l}\right)+b_{4}\left(C_{\mathrm{FeCl}_{3}}\right)$

where $\Delta \mathrm{p} / \Delta \mathrm{t}$ is the apparent penetration rate (microns/yr); $\mathrm{T}$ is the temperature $\left({ }^{\circ} \mathrm{C}\right) ; \mathrm{C}_{\mathrm{NaCl}}$ is the equivalent concentration of $\mathrm{NaCl}$ (wt. \%); and $\mathrm{C}_{\mathrm{FeCl}}$ is the concentration of $\mathrm{FeCl}_{3}$ (wt. \%). Within the bounds of thirty-eight (38) experimental observations for Alloy C-22, the coefficients were determined to be:

$b_{0}=+13.409$

$b_{1}=-5.5587$

$b_{2}=-0.87409$

$b_{3}=+0.56965$

$b_{4}=+0.60801$

More specifically, the correlation for Alloy C-22 is:

$\ln \left(\frac{\Delta p}{\Delta t}\right)=13.409-\left(\frac{5558.7}{T+273}\right)-0.87409(p H)+0.56965\left(C_{\mathrm{NaCl}}\right)+0.60801\left(C_{\mathrm{FeCl}_{3}}\right)$

The "standard error of estimate" $\left(\mathrm{s}_{\mathrm{y} / 1234}\right)$ and the "sample multiple variable regression coefficient" $\left(\mathrm{r}_{\mathrm{y} / 1234}\right)$ are defined by Crow, Davis and Maxfield [E. L. Crow, F. A. Davis, M. W. Maxfield, Statistics Manual, Dover Publications, Inc., New York, NY, 1960, pp. 147-19]. The "standard error of estimate" is a measure of the scatter of the observed penetration rates about the regression plane. About $95 \%$ of the points in a large sample are expected to lie within $\pm 2 \mathrm{~s}_{\mathrm{y} / 123 . \mathrm{k}}$ of the plane, measured in the $y$ direction. Values for the above correlation are:

$s_{y / 1234}=1.5092$

$r_{y / 1234}=0.65628$

The "multiple variable regression coefficient" indicates a reasonably good fit to the data set, given the large number of independent variables. As discussed in the literature, uncertainty in a given model parameter, $\beta_{\mathrm{j}}$, can be determined from the standard error of estimate, as shown by Eqns. 7 and 8 [E. L. Crow, F. A. Davis, M. W. Maxfield, Statistics Manual, Dover Publications, Inc., New York, NY, 1960, pp. 147-19]:

$s_{b_{j}}=s_{y / 123 k} \sqrt{n e_{i j}}$

$\beta_{j}=b_{j} \pm\left(t_{a / 2, n-k-1}\right) \times s_{b_{j}}$ 
This simple correlation has been tested within the bounds of anticipated conditions. The predictions appear to be reasonable for combinations of input parameters representative of the: Near Field Environment (NFE); SDW; SCW; SAW; SCMW; the unusually harsh, simulated crevice corrosion test of Asphahani $\left(10 \mathrm{wt} . \% \mathrm{FcCl}_{3}\right)$; and the conditions predicted during preliminary tests of the LLNL crevice transport model [J. C. Farmer, R. D. McCright, "Crevice Corrosion and Pitting of High-Level Waste Containers: Integration of Deterministic and Probabilistic Models," Paper No. 160, Annual Meeting of the National Association of Corrosion Engineers (NACE), Corrosion 98, San Diego, CA March 22-27, 1998]. The worst case within the bounds of the regression analysis is the simulated crevice condition used by Asphahani ( $10 \mathrm{wt}$. \% $\mathrm{FeCl}_{3}$ ). In the repository, the concentration of $\mathrm{FeCl}_{3}$ is expected to be limited to much lower values by the presence of carbonate, which precipitates iron. It must be noted that combinations of input parameters that are clearly beyond the range of the data included in the correlation cannot be used to generate reasonable predictions. Therefore, this correlation should not be used for saturated solutions of $\mathrm{J}-13$ and/or $\mathrm{FeCl}_{3}$. With in the limits of the experimental data, predictions are believed to be good representations of the observations.

For completeness, the above correlation also included observations of passive corrosion rate inferred from Ajit Roy's cyclic polarization measurements. It is well known that the corrosion (or penetration) rate of an alloy, $\mathrm{dp} / \mathrm{dt}$, can also be calculated from the corrosion current density, $\mathrm{i}_{\text {corr }}$, as follows:

$$
\frac{d p}{d t}=\frac{i_{\text {corr }}}{\rho_{\text {alloy }} n_{\text {alloy }} F}
$$

where $\rho_{\text {alloy }}$ is the density of the alloy, assumed to be approximately $8.4 \mathrm{~g} / \mathrm{cm}^{3}$, and F is Faraday's constant. The number of gram equivalents per gram of alloy, $\mathrm{n}_{\text {alloy }}$, is calculated with the following equation:

$$
n_{\text {alloy }}=\sum_{j}\left(\frac{f_{j} n_{j}}{a_{j}}\right)
$$

where $f_{j}$ is the mass fraction of the $j$-th alloying element in the material, $n_{j}$ are the number of electrons involved in the anodic dissolution process, which is assumed to be congruent, and $a_{j}$ is the atomic weight of the j-th alloying element. These equations have been used to calculate penetration rates for Alloy $\mathrm{C}-22$ from apparent corrosion currents determined during cyclic polarization measurements. In principle, such electrochemically-determined rates should be consistent with those observed in the LTCTF, though experience indicates that such electrochemically-determined rates are conservative (higher than those actually observed).

The magnitude of the observed rates shown in Figure 3 appear to be consistent with those quoted in the article by Smailos, Schwarzkopf, and Koster [E. Smailos, W. Schwarzkopf, R. Koster, "Corrosion Behaviour of Container Materials for the Disposal of High-Level Wastes in Rock Salt Formations," Nuclear Science and Technology, Commission of the European Communities, DUR 10400, 1986], though the correlation cannot be used at such high salt concentration since data from experiments with saturated solutions were not included in the correlation. Penetration rates for Alloy C-4 in a concentrated brine at 90,170 and $200^{\circ} \mathrm{C}$ are given. The authors state: "Hastelloy C-4 has also resisted pitting corrosion and stress corrosion cracking, in the absence of irradiation, and its corrosion rate has been low at all testing temperatures $(<1$ microns/yr), but it has been attacked by crevice corrosion." The authors go on to state 
that when it is exposed to gamma irradiation at $\sim 10^{5} \mathrm{rad} / \mathrm{hr}$, pitting corrosion was observed. This pitting corrosion is believed by several investigators in the field to be due to the formation of oxidants such as $\mathrm{H}_{2} \mathrm{O}_{2}$, which shift the corrosion potential in the anodic direction, closer to the pitting and repassivation potential. At LLNL in the mid 1980's, Glass performed definitive radiolysis experiments showing that the corrosion potential of $316 \mathrm{~L}$ stainless steel in $0.018 \mathrm{M} \mathrm{NaCl}$ at $30^{\circ} \mathrm{C}$ shifted from approximately -100 $\mathrm{mV}$ vs. SCE to approximately $+100 \mathrm{mV}$ vs. SCE when exposed to gamma irradiation $\left(3.3 \times 10^{6} \mathrm{rad} / \mathrm{hr}\right)$ from a Co-60 source [R. S. Glass et al., Gamma Radiation Effects on Corrosion: I. Electrochemical Mechanisms for the Aqueous Corrosion Processes of Austenitic Stainless Steels Relevant to Nuclear Waste Disposal in Tuff, Corrosion Science, Vol. 26, No. 8, 1986, p. 577-590; J. C. Farmer et al., "Corrosion Models for Performance Assessment of High-Level Radioactive-Waste Containers," Nuclear Engineering \& Design, Vol. 129, 1991, pp. 57-88]. The level of radiation expected at the outer surface of the CRM at the instant of CAM penetration is estimated to be orders-of-magnitude less than these exposures $\left(10^{5}-10^{6} \mathrm{rad} / \mathrm{hr}\right)$. At the Appendix 7 Meeting held at LLNL in February, 1998, the NRC said that they are ignoring the effects of radiolysis on corrosion, and believe that they are well justified in doing so. Note that radiolysis could form other oxidants, such as chlorine free radicals, ozone, and perhaps even unanticipated species such as peroxydisulfate, which has a very anodic redox potential. However, at low levels of radiation, the effects are not expected to be great. In regard to the C-4 penetration rate data, it must be noted that at high temperature, the expected rates for C-22 would be expected to be lower, as shown in Table 4. In regard to this table, two rates attact particular attention: Alloy $\mathrm{C}, 5$ wt. $\% \mathrm{FeCl}_{3}, 50^{\circ} \mathrm{C}, 0.075 \mathrm{~mm}$ crevice; Alloy $\mathrm{C}-276, \mathrm{H}_{2} \mathrm{SO}_{4}+\mathrm{HCl}+\mathrm{FeCl}_{3}+\mathrm{CuCl}_{2}, 50^{\circ} \mathrm{C}$.

Table 4. Published Penetration Rates (microns/yr) for Various Candidate CRM Alloys.

\begin{tabular}{|c|c|c|c|c|c|c|}
\hline Exposure & $\mathrm{T}\left({ }^{\circ} \mathrm{C}\right)$ & $\mathrm{C}$ & $\mathrm{C}-4$ & $\mathrm{C}-276$ & $\mathrm{C}-22$ & Source \\
\hline 10 wt. $\% \mathrm{FeCl}_{3}$ & 25 & & 7.6 & 5.1 & 2.5 & Haynes, 1987 \\
\hline 10 wt. $\% \mathrm{FeCl}_{3}$ & 50 & & 12.7 & 2.5 & 2.5 & Haynes, 1987 \\
\hline 10 wt. $\% \mathrm{FeCl}_{3}$ & 75 & & 508 & 12.7 & 12.7 & Haynes, 1987 \\
\hline 5 wt. $\% \mathrm{FeCl}_{3}$ & 50 & 20 & & & & Jackson \& van Rooyen, 1972 \\
\hline 5 wt. $\% \mathrm{CuCl}_{2}$ & 50 & 10 & & & & Jackson \& van Rooyen, 1972 \\
\hline 5 wt. $\% \mathrm{NaOCl}$ & 50 & 6 & & & & Jackson \& van Rooyen, 1972 \\
\hline 5 wt. $\% \mathrm{FeCl}_{3}+5$ wt. $\% \mathrm{HCl}$ & 25 & 20 & & & & Jackson \& van Rooyen, 1972 \\
\hline 5 wt. $\% \mathrm{FeCl}_{3} * * *$ & 50 & 5200 & & & & Jackson \& van Rooyen, 1972 \\
\hline 10 wt. $\% \mathrm{FeCl}_{3}$ & 25 & & & 5.08 & & Asphahani, 1980 \\
\hline 10 wt. $\% \mathrm{FeCl}_{3}$ & 50 & & & 5.08 & & Asphahani, 1980 \\
\hline Sea Water, Surface** & 25 & & & Nil & & Hack, 1983 \\
\hline Sea Water, 2370-6780 $\mathrm{ft}^{* *}$ & & & & Nil & & Reinhart, 1969 ( 24 samples $)$ \\
\hline $\begin{array}{l}7 \text { vol. } \% \mathrm{H}_{2} \mathrm{SO}_{4}+ \\
3 \text { vol. } \% \mathrm{HCl}+ \\
1 \text { wt. } \% \mathrm{FeCl}_{3}+ \\
1 \text { wt. } \% \mathrm{CuCl}_{2}\end{array}$ & 25 & & & 7.62 & & Asphahani, 1980 \\
\hline $\begin{array}{l}7 \text { vol. } \% \mathrm{H}_{2} \mathrm{SO}_{4}+ \\
3 \text { vol. } \% \mathrm{HCl}+ \\
1 \text { wt. } \% \mathrm{FeCl}_{3}+ \\
1 \text { wt. } \% \mathrm{CuCl}_{2} \\
\end{array}$ & 50 & & & 610 & & Asphahani, 1980 \\
\hline
\end{tabular}

Nomenclature: **Crevice sample *** Tight crevice $-0.075 \mathrm{~mm}$

Such high rates have not been observed with Alloy C-22 samples, configured in tight crevice geometries, and exposed to acidified ( $\mathrm{pH} \sim 2.7)$, concentrated $(1000 \mathrm{X}) \mathrm{J}-13$ well water at $90^{\circ} \mathrm{C}$. In cases where such high rates have been observed with lesser alloys such as C-4, the observed penetration rates for C-22 have 
remained low [Haynes, 1987, 10 wt. $\% \mathrm{FeCl}_{3}$ ]. This raises three important questions: (a) can the NRC repassivation potential criterion be applied to Alloys $\mathrm{C}, \mathrm{C}-4$ and $\mathrm{C}-276$ in cases where large penetration rates are predicted; (b) are measured penetration rates for Alloys $\mathrm{C}, \mathrm{C}-4$, and $\mathrm{C}-276$ in mixed strong acids really indicative of the rates expected for $\mathrm{C}-22$ in relevant repository environments; (c) are the $\mathrm{FeCl}_{3}$ environments reasonable simulations of a crevice; and (d) is the gradient in electric potential, or electric field, sufficient to induce complete separation of alkali metal cations and halide/oxy anions, thereby producing such an environment.? In regard to the last question, predictions based upon electic double layer theory indicate that electric fields of $10^{9} \mathrm{~V} / \mathrm{cm}$ at the electrode-electrolyte interface (across the compact double layer) may be possible. The field in the diffuse double layer is much less. The extreme field strengths in the compact double layer are believed to be sufficient to induce complete charge separation. However, since such gradients do not exist in the bulk electrolyte found in crevices, pits and cracks, what physical process could be responsible for creating concentrated mixtures of $\mathrm{H}_{2} \mathrm{SO}_{4}$ and $\mathrm{HCl}_{\text {? }}$ ? What plausible scenario can we provide to create environments where such high penetration rats have been observed?

Values for $1000 \mathrm{X} \mathrm{J}-13$ are based upon the above correlation, since the chloride concentration is within the range of data included in the correlation [J. C. Farmer et al., "Development of Corrosion Models for High-Level Waste Containers," Proc. $6^{\text {th }}$ International Conference on Nuclear Engineering, ICONE-6, San Dicgo, CA, May 10-15, 1998, ASME, 1998, 13 p.]. In the case of saturated J-13, estimates are based upon the article by Smailos, Schwarzkopf, and Koster [E. Smailos, W. Schwarzkopf, R. Koster, "Corrosion Behaviour of Container Materials for the Disposal of High-Level Wastes in Rock Salt Formations," Nuclear Science and Technology, Commission of the European Communities, DUR 10400, 1986], as interpreted by another member of the Expert Elicitation Panel [D. Shoesmith, "Passive Corrosion of the CRM," electronic mail message, February 13, 1998]. The data quoted by Shoesmith is for "Q-Brine" and "Z-Brine" electrolytes, as shown Table 5a.

Table 5a. Data for Passive Corrosion of Alloy C-4 in Saturated Brines (Smailos et al.; Shoesmith).

\begin{tabular}{|c|c|c|c|c|c|c|c|c|c|}
\hline Brine & $\mathrm{pH}$ & $\mathrm{NaCl}$ & $\mathrm{KCl}$ & $\mathrm{MgCl}_{2}$ & $\mathrm{MgSO}_{4}$ & $\mathrm{H}_{2} \mathrm{O}$ & $90^{\circ} \mathrm{C}$ Rate & $170^{\circ} \mathrm{C}$ Rate & $\mathrm{pH}$ \\
\hline & & wt. \% & wt. \% & wt. \% & wt. \% & wt. \% & $\mu \mathrm{m} / \mathrm{yr}$ & $\mu \mathrm{m} / \mathrm{yr}$ & Shoesmith \\
\hline $\mathrm{Q}$ & 4.9 & 1.4 & 4.7 & 26.8 & 1.4 & 65.7 & 0.02 & $0.15-0.66$ & $\sim 5$ \\
\hline $\mathrm{Z}$ & 3.6 & 0.2 & 0.66 & 36.4 & 0.87 & 61.9 & $10-14$ & & $\sim 2$ \\
\hline
\end{tabular}

The rate of 10-14 microns/yr for Alloy C-4 in Z-Brine at $90^{\circ} \mathrm{C}$ is interpreted as the "maximum possible" value by Shoesmith (taken here as rate at $99^{\text {th }}$ percentile). According to page 10 of the Smailos Report: "After three years of exposure until now Hastelloy C-4 has remained resistant to pitting corrosion, and to stress corrosion cracking. At $90^{\circ} \mathrm{C}$ local crevice corrosion attacks occurred at single points at the metal/PTFE and metal/metal contact surfaces with maxiumum depths of 250 microns (metal/PTFE), and 20-70 microns (metal/metal), respectively." This translates into a maximum penctration rate of 15-51 microns/yr. It must be noted that the rates from the Smailos et al. Report had to be scaled for $\mathrm{pH}$ and temperature so that all conditions of interest in this elicitation could be covered. While the base rate used was taken from the "Z-Brine" data, the activation energy used to scale the rate for temperature had to be inferred from the "Q-Brine" data. A very reasonable value of the activation energy, $\mathrm{E}_{\mathrm{a}}$, was estimated to be approximately $12 \mathrm{kcal} / \mathrm{mol}$. The estimate was made with the following equation, which is based upon an Ahrenius-type rate expression:

$$
\frac{r_{1}}{r_{2}}=\exp \left[\frac{E_{a}}{R}\left(\frac{1}{T_{2}}-\frac{1}{T_{1}}\right)\right]
$$


At $170^{\circ} \mathrm{C}\left(\mathrm{T}_{1}\right)$, the observed penetration rates were given as 0.66 amnd $0.15 \mathrm{microns} / \mathrm{yr}$, which were averaged to give a single value of 0.4 microns $/ y r\left(r_{1}\right)$. At a lower temperature of $90^{\circ} \mathrm{C}\left(\mathrm{T}_{2}\right)$, the observed rate was given as 0.02 microns/yr $\left(\mathrm{r}_{2}\right)$. Rates were scaled with the $\mathrm{pH}$ as implied by the correlation, since no better means of estimating the response is available. Therefore, the rates were assumed to obey the following empirical law:

$\frac{r_{1}}{r_{2}}=\exp \left[0.87409\left(p H_{2}-p H_{1}\right)\right]$

Establishment of CDF's for $1000 \mathrm{X}$ and saturated J-13 cases require estimation distribution width about the mean. In regard to estimates based upon either the correlation and Shoesmith's interpretation of data published by Smailos et al., it was assumed that logarithimic rates were distributed normally about the mean logarithmic rate. To determine the CDF's for $1000 \mathrm{X} \mathrm{J}-13$, which was based upon the correlation, the following simplifying approximations were made:

$$
\begin{aligned}
& y=\ln \left[\frac{\Delta p}{\Delta t}\right] \\
& y_{5 \%} \approx y_{\text {predicted }}-\delta y_{\alpha=0 \text { 05 }} \approx y_{\text {predicted }}-t_{\alpha=0 \text { 05 }} s_{123, k} \\
& y_{95 \%} \approx y_{\text {predicted }}+\delta y_{\alpha=0 \text { 05 }} \approx y_{\text {predicted }}+t_{\alpha=0 \text { 05 }} s_{y / 123 k} \\
& t_{\alpha=0.05} \approx 1.70 \\
& y_{1 \%} \approx y_{\text {predicted }}-\delta y_{\alpha=0 \text { 01 }} \approx y_{\text {predicted }}-t_{\alpha=0 \text { 01 }} s_{y / 123 k} \\
& y_{99 \%} \approx y_{\text {predicted }}+\delta y_{\alpha=0.01} \approx y_{\text {predicted }}+t_{\alpha-0.01} s_{y / 123 k} \\
& t_{\alpha=001} \approx 2.46 \\
& r_{5 \%}=\left[\frac{\Delta p}{\Delta t}\right]_{5 \%} \approx \exp \left[y_{\text {predicted }}-1.70 \times s_{y / 123} k\right] \\
& r_{95 \%}=\left[\frac{\Delta p}{\Delta t}\right]_{95 \%} \approx \exp \left[y_{\text {predicted }}+1.70 \times s_{y / 123 k}\right] \\
& r_{1 \%}=\left[\frac{\Delta p}{\Delta t}\right]_{1 \%} \approx \exp \left[y_{\text {predicted }}-2.46 \times s_{y / 123 k}\right] \\
& r_{99 \%}=\left[\frac{\Delta p}{\Delta t}\right]_{99 \%} \approx \exp \left[y_{\text {predicted }}+2.46 \times s_{y / 123 . k}\right]
\end{aligned}
$$


The CDF's based upon Smailos et al. assumed values at the $99^{\text {th }}$ and $50^{\text {th }}$ percentiles, and then assumed a log-normal distribution to estimate values at other percentiles. In this case, the standard deviation was estimated to be about 1.6228 , the value of $u_{\alpha=005}$ was assumed to be 1.645 and the value of $u_{\alpha=0}$ o1 was assumed to be 2.326. Based on the foregoing considerations, this member of the Expert Elicitation Panel proposes estimates for passive corrosion rates of the CRM represented by the CDF's summarized in Table $5 \mathrm{~b}$. Bold-face values correspond to rates taken from Table $5 \mathrm{a}$.

Table 5b. Estimates of CDF's for Passive Corrosion Rates of Alloy C-22 with Dripping.

\begin{tabular}{|c|c|c|c|c|c|c|c|c|}
\hline Data Source & & $\begin{array}{c}\text { Regression } \\
\text { (Farmer) }\end{array}$ & $\begin{array}{l}\text { Regression } \\
\text { (Farmer) }\end{array}$ & $\begin{array}{c}\text { Regression } \\
\text { (Farmer) }\end{array}$ & $\begin{array}{c}\text { Smailos } \\
\text { (Shoesmith) }\end{array}$ & \begin{tabular}{|c|} 
Smailos \\
(Shoesmith)
\end{tabular} & \begin{tabular}{|c|} 
Smailos \\
(Shoesmith)
\end{tabular} & $\begin{array}{c}\text { Smailos } \\
\text { (Shoesmith) }\end{array}$ \\
\hline Environment & & $1000 \times \mathrm{J}-13$ & $1000 \times \mathrm{J}-13$ & $1000 \mathrm{X} \mathrm{J}-13$ & 7-Brine & Z-Brine & Z-Brine & Z-Brine \\
\hline $\mathrm{NaCl}$ (wt. \%) & & 1.2 & 1.2 & 1.2 & Saturated & Saturated & Saturated & Saturated \\
\hline $\mathrm{T}\left({ }^{\circ} \mathrm{C}\right)$ & & 25 & 50 & 100 & 90 & 25 & 50 & 100 \\
\hline Percentile (\%) & $\mathrm{pH}$ & microns/yr & microns/yr & microns/yr & microns/yr & microns/yr & microns/yr & microns/yr \\
\hline 50 & 1 & $4.36 \times 10^{-3}$ & $1.85 \times 10^{-2}$ & $1.86 \times 10^{-1}$ & $6.60 \times 10^{-1}$ & $1.71 \times 10^{-2}$ & $8.29 \times 10^{-2}$ & 1.03 \\
\hline 50 & 2 & $1.82 \times 10^{-3}$ & $7.71 \times 10^{-3}$ & $7.74 \times 10^{-2}$ & $2.75 \times 10^{-1}$ & $7.13 \times 10^{-3}$ & $3.46 \times 10^{-2}$ & $4.31 \times 10^{-1}$ \\
\hline 50 & 3 & $7.59 \times 10^{-4}$ & $3.22 \times 10^{-3}$ & $3.23 \times 10^{-2}$ & $1.15 \times 10^{-1}$ & $2.98 \times 10^{-3}$ & $1.44 \times 10^{-2}$ & $1.80 \times 10^{-1}$ \\
\hline 50 & 5 & $1.32 \times 10^{-4}$ & $5.60 \times 10^{-4}$ & $5.62 \times 10^{-3}$ & $2.00 \times 10^{-2}$ & $5.18 \times 10^{-4}$ & $2.51 \times 10^{-3}$ & $3.13 \times 10^{-2}$ \\
\hline 50 & 7 & $2.30 \times 10^{-5}$ & $9.75 \times 10^{-5}$ & $9.79 \times 10^{-4}$ & $3.48 \times 10^{-3}$ & $9.02 \times 10^{-5}$ & $4.38 \times 10^{-4}$ & $5.46 \times 10^{-3}$ \\
\hline 50 & 10 & $1.67 \times 10^{-6}$ & $7.08 \times 10^{-6}$ & $7.11 \times 10^{-5}$ & $2.53 \times 10^{-4}$ & $6.55 \times 10^{-6}$ & $3.18 \times 10^{-5}$ & $3.96 \times 10^{-4}$ \\
\hline Percentile (\%) & $\mathrm{pH}$ & microns/yr & microns/yr & microns/yr & microns/yr & microns/yr & microns/yr & microns/yr \\
\hline 5 & 1 & $3.35 \times 10^{-4}$ & $1.42 \times 10^{-3}$ & $1.43 \times 10^{-2}$ & $4.57 \times 10^{-2}$ & $1.18 \times 10^{-3}$ & $5.75 \times 10^{-3}$ & $7.16 \times 10^{-2}$ \\
\hline 5 & 2 & $1.40 \times 10^{-4}$ & $5.93 \times 10^{-4}$ & $5.95 \times 10^{-3}$ & $1.91 \times 10^{-2}$ & $4.94 \times 10^{-4}$ & $2.40 \times 10^{-3}$ & $2.99 \times 10^{-2}$ \\
\hline 5 & 3 & $5.84 \times 10^{-5}$ & $2.47 \times 10^{-4}$ & $2.48 \times 10^{-3}$ & $7.96 \times 10^{-3}$ & $2.06 \times 10^{-4}$ & $1.00 \times 10^{-3}$ & $1.25 \times 10^{-2}$ \\
\hline 5 & 5 & $1.02 \times 10^{-5}$ & $4.31 \times 10^{-5}$ & $4.32 \times 10^{-4}$ & $1.39 \times 10^{-3}$ & $3.59 \times 10^{-5}$ & $1.74 \times 10^{-4}$ & $2.17 \times 10^{-3}$ \\
\hline 5 & 7 & $1.77 \times 10^{-6}$ & $7.49 \times 10^{-6}$ & $7.53 \times 10^{-5}$ & $2.41 \times 10^{-4}$ & $6.25 \times 10^{-6}$ & $3.03 \times 10^{-5}$ & $3.78 \times 10^{-4}$ \\
\hline 5 & 10 & $1.29 \times 10^{-7}$ & $5.44 \times 10^{-7}$ & $5.47 \times 10^{-6}$ & $1.75 \times 10^{-5}$ & $4.54 \times 10^{-7}$ & $2.20 \times 10^{-6}$ & $2.75 \times 10^{-5}$ \\
\hline Percentile (\%) & $\mathrm{pH}$ & microns/yr & microns/yr & microns/yr & microns/yr & microns/yr & microns/yr & microns/yr \\
\hline 95 & 1 & $5.67 \times 10^{-2}$ & $2.40 \times 10^{-1}$ & 2.41 & 9.52 & $2.47 \times 10^{-1}$ & 1.20 & 14.9 \\
\hline 95 & 2 & $2.37 \times 10^{-2}$ & $1.00 \times 10^{-1}$ & 1.01 & 3.97 & $1.03 \times 10^{-1}$ & $4.99 \times 10^{-1}$ & 6.23 \\
\hline 95 & 3 & $9.88 \times 10^{-3}$ & $4.19 \times 10^{-2}$ & $4.20 \times 10^{-1}$ & 1.66 & $4.30 \times 10^{-2}$ & $2.08 \times 10^{-1}$ & 2.60 \\
\hline 95 & 5 & $1.72 \times 10^{-3}$ & $7.29 \times 10^{-3}$ & $7.32 \times 10^{-2}$ & $2.89 \times 10^{-1}$ & $7.48 \times 10^{-3}$ & $3.63 \times 10^{-2}$ & $4.52 \times 10^{-1}$ \\
\hline 95 & 7 & $2.99 \times 10^{-4}$ & $1.27 \times 10^{-3}$ & $1.27 \times 10^{-2}$ & $5.03 \times 10^{-2}$ & $1.30 \times 10^{-3}$ & $6.31 \times 10^{-3}$ & $7.87 \times 10^{-2}$ \\
\hline 95 & 10 & $2.17 \times 10^{-5}$ & $9.21 \times 10^{-5}$ & $9.25 \times 10^{-4}$ & $3.65 \times 10^{-3}$ & $9.46 \times 10^{-5}$ & $4.59 \times 10^{-4}$ & $5.72 \times 10^{-3}$ \\
\hline Percentile (\%) & $\mathrm{pH}$ & microns/yr & microns/yr & microns/yr & microns/yr & microns/yr & microns/yr & microns/yr \\
\hline 1 & 1 & $1.06 \times 10^{-4}$ & $4.51 \times 10^{-4}$ & $4.53 \times 10^{-3}$ & $1.51 \times 10^{-2}$ & $3.92 \times 10^{-4}$ & $1.90 \times 10^{-3}$ & $2.37 \times 10^{-2}$ \\
\hline 1 & 2 & $4.44 \times 10^{-5}$ & $1.88 \times 10^{-4}$ & $1.89 \times 10^{-3}$ & $6.32 \times 10^{-3}$ & $1.64 \times 10^{-4}$ & $7.94 \times 10^{-4}$ & $9.90 \times 10^{-3}$ \\
\hline 1 & 3 & $1.85 \times 10^{-5}$ & $7.85 \times 10^{-5}$ & $7.89 \times 10^{-4}$ & $2.64 \times 10^{-3}$ & $6.83 \times 10^{-5}$ & $3.31 \times 10^{-4}$ & $4.13 \times 10^{-3}$ \\
\hline 1 & 5 & $3.23 \times 10^{-6}$ & $1.37 \times 10^{-5}$ & $1.37 \times 10^{-4}$ & $4.59 \times 10^{-4}$ & $1.19 \times 10^{-5}$ & $5.77 \times 10^{-5}$ & $7.19 \times 10^{-4}$ \\
\hline 1 & 7 & $5.62 \times 10^{-7}$ & $2.38 \times 10^{-6}$ & $2.39 \times 10^{-5}$ & $7.99 \times 10^{-5}$ & $2.07 \times 10^{-6}$ & $1.00 \times 10^{-5}$ & $1.25 \times 10^{-4}$ \\
\hline 1 & 10 & $4.08 \times 10^{-8}$ & $1.73 \times 10^{-7}$ & $1.74 \times 10^{-6}$ & $5.80 \times 10^{-6}$ & $1.50 \times 10^{-7}$ & $7.29 \times 10^{-1}$ & $9.09 \times 10^{-6}$ \\
\hline Percentile $(\%)$ & $\mathrm{pH}$ & microns/yr & microns/yr & microns/yr & microns/yr & microns/yr & microns/yr & microns/yr \\
\hline 99 & 1 & $1.79 \times 10^{-1}$ & $7.57 \times 10^{-1}$ & 7.60 & 28.8 & $7.45 \times 10^{-1}$ & 3.61 & 45.1 \\
\hline 99 & 2 & $7.45 \times 10^{-2}$ & $3.16 \times 10^{-1}$ & 3.17 & 12.0 & $3.11 \times 10^{-1}$ & 1.51 & 18.8 \\
\hline 99 & 3 & $3.11 \times 10^{-2}$ & $1.32 \times 10^{-1}$ & 1.32 & 5.01 & $1.30 \times 10^{-1}$ & $6.29 \times 10^{-1}$ & 7.84 \\
\hline 99 & 5 & $5.41 \times 10^{-3}$ & $2.29 \times 10^{-2}$ & $2.30 \times 10^{-1}$ & $8.72 \times 10^{-1}$ & $2.26 \times 10^{-2}$ & $1.10 \times 10^{-1}$ & 1.37 \\
\hline 99 & 7 & $9.43 \times 10^{-4}$ & $3.99 \times 10^{-3}$ & $4.01 \times 10^{-2}$ & $1.52 \times 10^{-1}$ & $3.93 \times 10^{-3}$ & $1.91 \times 10^{-2}$ & $2.38 \times 10^{-1}$ \\
\hline 99 & 10 & $6.85 \times 10^{-5}$ & $2.90 \times 10^{-4}$ & $2.91 \times 10^{-3}$ & $1.10 \times 10^{-2}$ & $2.86 \times 10^{-4}$ & $1.39 \times 10^{-3}$ & $1.73 \times 10^{-2}$ \\
\hline
\end{tabular}


Estimates for humid air corrosion assume rates comparable to those for aqueous-phase passive corrosion at neutral $\mathrm{pH}$, which appears to be more or less consistent with the impressive "mirror finish" of an Alloy $\mathrm{C}$ sample after 56 years exposure to a coastal environment on the coast of North Carolina (Table 5c).

Table 5c. Estimates of CDF's for Passive Corrosion Rates of Alloy C-22 in Humid Air - Humid Air Corrosion.

\begin{tabular}{|c|c|c|c|}
\hline $\mathrm{T}\left({ }^{\circ} \mathrm{C}\right)$ & 25 & 50 & 100 \\
\hline Percentile (\%) & microns/yr & microns/yr & microns/yr \\
\hline 1 & $5.62 \times 10^{-7}$ & $2.38 \times 10^{-6}$ & $2.39 \times 10^{-5}$ \\
\hline 5 & $1.77 \times 10^{-6}$ & $7.49 \times 10^{-6}$ & $7.53 \times 10^{-5}$ \\
\hline 50 & $2.30 \times 10^{-5}$ & $9.75 \times 10^{-5}$ & $9.79 \times 10^{-4}$ \\
\hline 95 & $2.99 \times 10^{-4}$ & $1.27 \times 10^{-3}$ & $1.27 \times 10^{-2}$ \\
\hline 99 & $9.43 \times 10^{-4}$ & $3.99 \times 10^{-3}$ & $4.01 \times 10^{-2}$ \\
\hline
\end{tabular}

\section{PIT INITIATION PROBABILITY}

\section{Questions:}

3) What is the probability of initiating localized (crevice) corrosion of the inner barrier under the following conditions?

$\mathrm{T}=25^{\circ} \mathrm{C}$

1) $\mathrm{pH} 2.5$ and potential of $340 \mathrm{mV}$ and $640 \mathrm{mV}$ vs. SHE

2) $\mathrm{pH} \mathrm{3-10}$ and potential of $340 \mathrm{mV}$ vs. SHE

$\mathrm{T}=50^{\circ} \mathrm{C}$

1) $\mathrm{pH} 2.5$ and potential of $340 \mathrm{mV}$ and $640 \mathrm{mV}$ vs. SHE

2) $\mathrm{pH} \mathrm{3-10} \mathrm{and} \mathrm{potential} \mathrm{of} 340 \mathrm{mV}$ vs. SHE

$\mathrm{T}=100^{\circ} \mathrm{C}$

1) $\mathrm{pH} 2.5$ and potential of $340 \mathrm{mV}$ and $640 \mathrm{mV}$ vs. SHE

2) $\mathrm{pH} \mathrm{3-10}$ and potential of $340 \mathrm{mV}$ vs. SHE

\section{Response:}

The probability of localized corrosion, which is assumed to include both crevice corrosion and pit initiation, is based upon observations of the pitting and repassivation potential. First, all observed values are placed on a common potential scale, that of the standard hydrogen electrode (SIIE). Correlations have been obtained for the electrochemical potentials of the $\mathrm{AgCl}$ and SCE reference electrodes as functions of temperature. The first correlation for $\mathrm{Ag} / \mathrm{AgCl} / 0.1 \mathrm{M} \mathrm{KCl}$ was provided by David Shoesmith and was developed by AECL [King et al., "A High-Temperature, High-Pressure, Silver-Silver Chloride Reference Electrode: A User's Guide," AECL-9890, 1989].

$$
E_{A g C l}(S H E)=0.23755-5.3783 \times 10^{-4} T\left({ }^{\circ} \mathrm{C}\right)-2.3728 \times 10^{-6} T\left({ }^{\circ} \mathrm{C}\right)^{2}+2.2671 \times 10^{-4}\left[T\left({ }^{\circ} \mathrm{C}\right)+273\right]
$$

The second correlation for $\mathrm{Hg} / \mathrm{Hg}_{2} \mathrm{Cl}_{2}$ /satd. $\mathrm{KCl}$ was obtained from the well-known text by Bard \& Faulkner [A. J. Bard, L. R. Faulkner, Electrochemical Methods, Fundamentals and Applications, John Wiley \& Sons, New York, NY, 1980]. 


$$
E_{S C E}(S H E)=0.2412-6.61 \times 10^{-4}\left[T\left({ }^{\circ} \mathrm{C}\right)-25\right]-1.75 \times 10^{-6}\left[T\left({ }^{\circ} \mathrm{C}\right)-25\right]^{2}-9.0 \times 10^{-10}\left[T\left({ }^{\circ} \mathrm{C}\right)-25\right]^{3}
$$

Relevant temperature corrections can be calculated with each of these expressions, as given in Table 6 below:

Table 6. Correction of Reference Electrodes for Excursions from Ambient Temperature.

\begin{tabular}{|l|l|l|}
\hline $\mathrm{T}\left({ }^{\circ} \mathrm{C}\right)$ & $\mathrm{E}_{\mathrm{Ag} / \mathrm{AgCl} / 0 \mathrm{M} \mathrm{KCl}}$ (V vs. SHE) & $\mathrm{E}_{\mathrm{SCE}}$ (V vs. SHE) \\
\hline 25 & 0.2902 & 0.2412 \\
\hline 60 & 0.2722 & 0.2344 \\
\hline 90 & 0.2629 & 0.1906 \\
\hline 95 & 0.2485 & 0.1861 \\
\hline
\end{tabular}

In the case of the $\mathrm{Ag} / \mathrm{AgCl} / 0.1 \mathrm{M} \mathrm{KCl}$ electrode, the potential must also bc corrected for electrolyte concentration, so that it is applicable for the standard $\mathrm{AgCl}$ electrode with saturated $\mathrm{KCl}$. First, the solubility of $\mathrm{KCl}$ as a function of temperature is obtained from the CRC Handbook [CRC Handbook, Chemical Rubber Company, $61^{\text {st }}$ Edition, 1980-81, p. B-132].

$T=20^{\circ} \mathrm{C}: \quad C_{\text {saturated } K C l}=23.8$ grams per $100 \mathrm{cc}$

$T=100^{\circ} \mathrm{C}: \quad C_{\text {saurated } K C l}=56.7$ grams per $100 \mathrm{cc}$

The saturation concentrations at other temperatures is estimated by simple linear interpolation, as shown in Table 7:

Table 7. Saturation Concentration of KCl by Linear Interpolation.

\begin{tabular}{|l|l|l|}
\hline $\mathrm{T}\left({ }^{\circ} \mathrm{C}\right)$ & $\mathrm{C}_{\text {saturated } \mathrm{KCl}}(\mathrm{g}$ per100 cc) & $\mathrm{C}_{\text {saturated } \mathrm{KCl}}(\mathrm{mol} / \mathrm{kg})$ \\
\hline 20 & 23.8 & 3.192 \\
\hline 25 & 25.86 & 3.468 \\
\hline 60 & 40.25 & 5.398 \\
\hline 90 & 52.59 & 7.053 \\
\hline 95 & 54.64 & 7.329 \\
\hline 100 & 56.7 & 7.605 \\
\hline
\end{tabular}

Note that a formula weight of $\mathrm{KCl}$ is assumed to be approximately 74.56 , and ignores any hydration effects. Obviously, we have ignored activity coefficients. The Debye-Huckel equation could be used to esitmate the activity coefficients, however, it only applies rigorously to infinitely dilute solutions. Other activity coefficient models for higher electrolyte concentrations are controversial, due to a general lack of knowledge of the sphere of hydration surrounding individual ions, a general inability to account for Coulombic and dipole interactions between each pair of individual ions, and other equally important effects. A simplification of the Nernst equation, which also ignores activity coefficients, can be used to make a first order correction of the potential of the $\mathrm{Ag} / \mathrm{AgCl} / \mathrm{KCl}$ reference electrode for $\mathrm{KCl}$ concentration. The Nernst equation can be written as:

$$
E=E^{0}+\frac{R T}{n F} \ln \frac{C_{O}}{C_{R}}
$$

where the convention is assumed to be: 
$O+n e^{-} \stackrel{\text { electrode }}{\longrightarrow} R$

Application of this simplified Nernst equation to the $\mathrm{Ag} / \mathrm{AgCl} / \mathrm{KCl}$ reference electrode yields:

$$
E_{A g / A g C l / \text { satd } K C l}-E_{A g / A g C l / 01 M K C l}=-\frac{R T}{F} \ln \frac{C_{\text {satd } . K C l}}{C_{01 M K C l}}
$$

where the assumed reaction is:

$$
\mathrm{AgCl}+\mathrm{e}^{-} \longrightarrow \mathrm{Ag}+\mathrm{Cl}^{-}
$$

Given Faraday's constant of $9.64846 \times 10^{4} \mathrm{C} /$ equiv, the value of $\mathrm{RT} / \mathrm{F}$ at $25^{\circ} \mathrm{C}$ is $0.02569 \mathrm{~V}$, and can be scaled to different temperatures (Table 8). Application of these corrections to measured corrosion, pitting, and repassivation potentials is summarized in Tables $9 \mathrm{a}$ and $9 \mathrm{~b}$. Note that the interpretation of cyclic polarization (CP) curves is very subjective. Where more than one inflection point might be interpreted as the potential of interest, the most conservative value was chosen (least anodic repassivation potential, for cxample). These data are summarized in Figure 4.

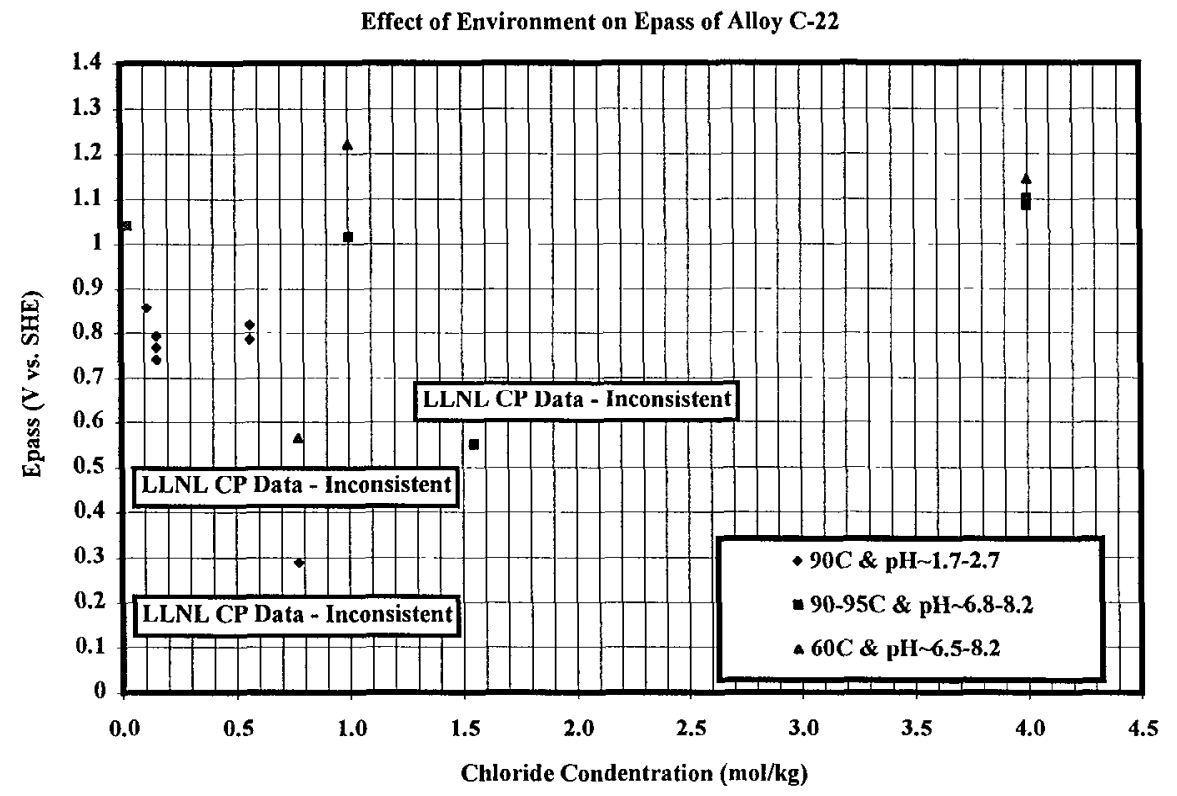

Figure 4. Observations of repassivation potential as a function of chloride, temperature, and $p H$.

Table 8. Correction of Ag/AgCl Reference Electrode Potenial for Concentration.

\begin{tabular}{|l|l|l|l|l|l|l|}
\hline $\mathrm{T}\left({ }^{\circ} \mathrm{C}\right)$ & $\mathrm{RT} / \mathrm{F}(\mathrm{V})$ & $\begin{array}{l}\mathrm{E}_{\mathrm{Ag} / \mathrm{AgCl} / 01 \mathrm{M} \mathrm{KCl}} \\
(\mathrm{V} \text { vs. SHE) }\end{array}$ & $\begin{array}{l}\mathrm{C}_{\text {saturated KCl }} \\
(\mathrm{mol} / \mathrm{kg})\end{array}$ & $\begin{array}{l}\text { Concentration } \\
\text { Correction (V) }\end{array}$ & $\begin{array}{l}\mathrm{E}_{\text {Ag/AgCl/satd KCl }} \\
\text { (V vs. SHE) }\end{array}$ & $\begin{array}{l}\mathrm{E}_{\mathrm{SCE}} \\
(\mathrm{V} \text { vs. SHE) }\end{array}$ \\
\hline 25 & 0.02569 & 0.2902 & 3.468 & -0.0911 & 0.1991 & 0.2412 \\
\hline 60 & 0.02871 & 0.2722 & 5.398 & -0.1145 & 0.1577 & 0.2344 \\
\hline 90 & 0.03129 & 0.2629 & 7.053 & -0.1332 & 0.1297 & 0.1906 \\
\hline 95 & 0.03172 & 0.2485 & 7.329 & -0.1362 & 0.1123 & 0.1861 \\
\hline
\end{tabular}


Table 9a. Corrosion and Threshold Potentials (vs. SHE) for Alloy C-22 Measured by LLNL \& NRC.

\begin{tabular}{|c|c|c|c|c|c|c|c|c|c|c|c|}
\hline Source & $\mathrm{ID}$ & $\mathrm{T}$ & $\mathrm{T}$ & $\mathrm{NaCl}$ & $\mathrm{FeCl}_{3}$ & $\mathrm{Cl}^{-}$ & $\mathrm{pH}$ & $\mathrm{E}_{\text {corr }}$ & $\mathrm{E}_{\text {pit }}-$ low & $\mathrm{E}_{\text {pit }}-$ high & $\mathrm{E}_{\text {pass }}$ \\
\hline & & $\mathrm{C}$ & $\mathrm{K}$ & $\mathrm{Wt} . \%$ & $\mathrm{Wt} . \%$ & $\mathrm{~mol} / \mathrm{kg}$ & & $\mathrm{V}$ vs. Ref. & V vs. Ref. & V vs. Ref. & V vs. Ref. \\
\hline LLNL & $090996 \mathrm{Cl}$ & 90 & 363 & 10.00 & 0 & 1.552 & 6.83 & -0.154 & 0.312 & 0.312 & 0.42 \\
\hline LLNL & $103397 \mathrm{Cl}$ & 90 & 363 & 1.00 & 0 & 0.155 & 2.69 & -0.159 & 0.628 & 0.733 & 0.663 \\
\hline LLNL & $102497 \mathrm{C} 2$ & 90 & 363 & 1.00 & 0 & 0.155 & 2.67 & -0.162 & 0.628 & 0.785 & 0.611 \\
\hline LLNL & $102797 \mathrm{C} 1$ & 90 & 363 & 5.00 & 0 & 0.776 & 2.69 & -0.202 & 0.423 & 0.654 & 0.158 \\
\hline LLNL & $081997 \mathrm{C} 1$ & 90 & 363 & 1.00 & 0 & 0.155 & 2.69 & -0.145 & 0.59 & 0.687 & 0.638 \\
\hline LLNL & $082697 \mathrm{C} 2$ & 60 & 333 & 5.00 & 0 & 0.776 & 6.53 & -0.105 & 0.393 & 0.448 & 0.407 \\
\hline LLNL & $110497 \mathrm{C} 2$ & 90 & 363 & 0.00 & 0.61 & 0.113 & 2.14 & 0.531 & 0.775 & 0.829 & 0.727 \\
\hline LLNL & $103097 \mathrm{C} 1$ & 90 & 363 & 0.00 & 3.05 & 0.564 & 1.72 & 0.584 & 0.759 & 0.766 & 0.655 \\
\hline LLNL & $103197 \mathrm{C} 2$ & 90 & 363 & 0.00 & 3.05 & 0.564 & 1.72 & 0.439 & 0.838 & 0.872 & 0.688 \\
\hline NRC & $\mathrm{C} 22-1$ & 95 & 368 & 25.78 & 0 & 4.000 & 8.2 & & & & 0.916 \\
\hline NRC & $\mathrm{C} 22-2$ & 95 & 368 & 25.78 & 0 & 4.000 & 8.2 & & & & 0.911 \\
\hline NRC & $\mathrm{C} 22-3$ & 95 & 368 & 25.78 & 0 & 4.000 & 8.2 & & & & 0.9 \\
\hline NRC & $\mathrm{C} 22-4$ & 60 & 333 & 25.78 & 0 & 4.000 & 8.2 & & & & 0.911 \\
\hline NRC & $\mathrm{C} 22-5$ & 95 & 368 & 6.44 & 0 & 1.000 & 8.2 & & & & 0.829 \\
\hline NRC & $\mathrm{C} 22-6$ & 60 & 333 & 6.44 & 0 & 1.000 & 8.2 & & & & 0.986 \\
\hline NRC & $\mathrm{C} 22-7$ & 95 & 368 & 0.18 & 0 & 0.028 & 8.2 & & & & 0.854 \\
\hline
\end{tabular}

Table 9b. Corrosion and Threshold Potentials (vs. SHE) for Alloy C-22 Measured by LLNL \& NRC.

\begin{tabular}{|c|c|c|c|c|c|c|c|}
\hline ID & Reference & Correction & Ecorr & Epit - low & Epit - high & Epass & Comments \\
\hline & & $\mathrm{V}$ & V vs. SHE & V vs. SHE & V vs. SHE & V vs. SHE & \\
\hline $090996 \mathrm{Cl} 1$ & $\mathrm{Ag} / \mathrm{AgCl} / \mathrm{KCl}$ & 0.1297 & -0.0243 & 0.4417 & 0.4417 & 0.5497 & inconsistent \\
\hline $103397 \mathrm{Cl} 1$ & $\mathrm{Ag} / \mathrm{AgCl} / \mathrm{KCl}$ & 0.1297 & -0.0293 & 0.7577 & 0.8627 & 0.7927 & \\
\hline $102497 \mathrm{C} 2$ & $\mathrm{Ag} / \mathrm{AgCl} / \mathrm{KCl}$ & 0.1297 & -0.0323 & 0.7577 & 0.9147 & 0.7407 & \\
\hline $102797 \mathrm{C} 1$ & $\mathrm{Ag} / \mathrm{AgCl} / \mathrm{KCl}$ & 0.1297 & -0.0723 & 0.5527 & 0.7837 & 0.2877 & inconsistent \\
\hline $081997 \mathrm{C} 1$ & $\mathrm{Ag} / \mathrm{AgCl} / \mathrm{KCl}$ & 0.1297 & -0.0153 & 0.7197 & 0.8167 & 0.7677 & \\
\hline $082697 \mathrm{C} 2$ & $\mathrm{Ag} / \mathrm{AgCl} / \mathrm{KCl}$ & 0.1577 & 0.0527 & 0.5507 & 0.6057 & 0.5647 & inconsistent \\
\hline $110497 \mathrm{C} 2$ & $\mathrm{Ag} / \mathrm{AgCl} / \mathrm{KCl}$ & 0.1297 & 0.6607 & 0.9047 & 0.9587 & 0.8567 & \\
\hline $103097 \mathrm{C} 1$ & $\mathrm{Ag} / \mathrm{AgCl} / \mathrm{KCl}$ & 0.1297 & 0.7137 & 0.8887 & 0.8957 & 0.7847 & \\
\hline $103197 \mathrm{C} 2$ & $\mathrm{Ag} / \mathrm{AgCl} / \mathrm{KCl}$ & 0.1297 & 0.5687 & 0.9677 & 1.0017 & 0.8177 & \\
\hline $\mathrm{C} 22-1$ & $\mathrm{SCE}$ & 0.1861 & & & & 1.1021 & \\
\hline $\mathrm{C} 22-2$ & $\mathrm{SCE}$ & 0.1861 & & & & 1.0971 & \\
\hline $\mathrm{C} 22-3$ & $\mathrm{SCE}$ & 0.1861 & & & & 1.0861 & \\
\hline $\mathrm{C} 22-4$ & $\mathrm{SCE}$ & 0.2344 & & & & 1.1454 & \\
\hline $\mathrm{C} 22-5$ & $\mathrm{SCE}$ & 0.1861 & & & & 1.0151 & \\
\hline $\mathrm{C} 22-6$ & $\mathrm{SCE}$ & 0.2344 & & & & 1.2204 & \\
\hline $\mathrm{C} 22-7$ & $\mathrm{SCE}$ & 0.1861 & & & & 1.0401 & \\
\hline
\end{tabular}

The probability of initiating localized corrosion are based on the stochastic probability theory of pit initiation, as discussed by Baroux [B. Baroux, "Further Insights on the Pitting Corrosion of Stainless Steels," Chapter 9, Corrosion Mechanisms in Theory and Practice, P. Marcus, J. Oudar, Eds., Marcel Dekker, Inc., New York, NY, pp. 265-309]. First, the expression for the survival probability is:

$\delta P_{S}=1-\bar{\omega} \times \delta S$ 
where $\delta \mathrm{P}$ is the survival probability (probability of no pitting) of an infinitesimal area $\delta \mathrm{S}$ on a sample of area $S$. The survival probability of the entire surface $S$ is then:

$$
P_{S}=[1-\bar{\omega} \times \delta S]^{\frac{S}{\alpha S}}
$$

The pit generation rate, PGR, is then defined in terms of the time derivative of the elementary pitting probability:

$$
\begin{aligned}
& \frac{d \bar{\omega}}{d t}=g=P G R \\
& \bar{\omega}=\int_{0}^{t}(P G R) d t
\end{aligned}
$$

We then make the following simplification by assuming that PGR is independent of time and that $\delta S \sim \mathrm{S}$. While it would be better to avoid such gross over simplification, it does provide some degree of insight into the expected dependence of the survival probability, and the probability of pit initiation, on electrochemical potential. This insight is needed to address the question regarding probability of pitting.

$P_{S} \approx 1-P G R \times t \times S$

The probability of pitting (localized corrosion, I,C) is then assumed to be:

$P_{L C} \approx P G R \times t \times S$

It is observed empirically that:

$\ln (P G R) \approx \beta\left(E-E_{p i t}\right)$

Therefore:

$\ln \left(\frac{P_{L C, 1}}{P_{L C, 2}}\right) \approx \ln \left(\frac{P G R_{1}}{P G R_{2}}\right) \approx \beta\left(E_{1}-E_{2}\right)$

We can estimate the empirical constant $\beta$ as:

$\beta=\frac{\ln \left(P_{L C, 1} / P_{L C, 2}\right)}{\left(E_{1}-E_{2}\right)}$

Now, for illustration, consider a hypothetical case where the repassivation potential is assumed to be the point at which there is a 5\% chance of initiating localized corrosion. Furthermore, assume that the average repassivation potential is $800 \mathrm{mV}$ vs. SHE, and that the observed scatter around the averate \pm 50 $\mathrm{mV}$. The probability of initiating localized corrosion at $800 \mathrm{mV}$ vs. SHE is assumed to be $5 \%$, and the probability of initiating localized corrosion at $800-50 \mathrm{mV}$ vs. SHE is assumed to be $1 \%$. In this case, 


$$
\beta=\frac{\ln (5 / 1)}{(800 m V-750 m V)} \approx 0.032 m V^{-1}
$$

The CDF based upon these simplification and assumptions are summarized in Table 10a, where the recommended case is Case 3 . It should be noted that the maximum probability of pitting is believed to be less than a $15 \%\left(99^{\text {th }}\right.$ percentile, $\left.\mathrm{pH} 2.5,640 \mathrm{mV}\right)$, with typical values of $0.01-2.12 \%$ (Table $10 \mathrm{~b}$ ).

\section{4) What is the localized corrosion rate of the C-22 inner barrier?}

The expert assessments to date have provided two alternative ways to model localized corrosion of the inner barrier: a) "exponential" pit growth law, and b) "logarithmic" pit growth law: Exponential crevice growth law is expressed as follows:

$p=B \times t^{n}$

where $\mathrm{p}$ is the crevice depth, $\mathrm{B}$ is a constant, $\mathrm{t}$ is time, and $\mathrm{n}$ is an exponent. Distributions for the constants $\mathrm{B}$ and $\mathrm{n}$ have been provided. A crevice corrosion model suggested recently by LLNL belongs to this type $(n=1 / 2$ corresponding to a diffusion-controlled penetration rate). Logarithmic crevice growth law is expressed as follows:

$$
p=k \times \exp \left[\frac{Q}{T}\right] \times \log [t]-x_{0}
$$

where $\mathrm{k}, \mathrm{Q}$ and $\mathrm{x}_{0}$ are constants, $\mathrm{T}$ is temperature, and $\mathrm{t}$ is time. Distributions for the constants $\mathrm{k}, \mathrm{Q}$ and $\mathrm{x}_{0}$ have been provided. Please express your assessment of corrosion rate using either of these functional forms (or another of your choice). Please consider the following conditions:

$\mathrm{T}=25^{\circ} \mathrm{C}$

1) $\mathrm{pH} 2.5$ and potential of $340 \mathrm{mV}$ and $640 \mathrm{mV}$ vs. SHE

2) $\mathrm{pH} \mathrm{3-10}$ and potential of $340 \mathrm{mV}$ vs. SHE

$\mathrm{T}=50^{\circ} \mathrm{C}$

1) $\mathrm{pH} 2.5$ and potential of $340 \mathrm{mV}$ and $640 \mathrm{mV}$ vs. SHE

2) $\mathrm{pH} \mathrm{3-10} \mathrm{and} \mathrm{potential} \mathrm{of} 340 \mathrm{mV}$ vs. SHE $\mathrm{T}=100^{\circ} \mathrm{C}$

1) $\mathrm{pH} 2.5$ and potential of $340 \mathrm{mV}$ and $640 \mathrm{mV}$ vs. SHE

2) $\mathrm{pH} 3-10$ and potential of $340 \mathrm{mV}$ vs. SHE

Uncertainties in the coefficients of the growth laws should be expressed by, as a minimum, the Oth and 100 th percentile values along with the median, 5th percentile and 95th percentile values.

\section{Response:}

$\Lambda$ s pointed out by Prof. Scully, the "logarithmic" cxpression has some very attractive features. However, there is an obvious inconsistency in the expression as presented in the elicitation question. It is recommended that this be resolved by using $\log (1+t)$ instead of $\log (t)$. This Panel member prefers the "exponential form" since it is easily interpreted in terms of diffusion-controlled penetration or other easily 
visualized phenomena. The penetration rates for localized corrosion shown in Tables 12 are based on Asphahani's data for Alloys C-22 and C-276, which are summarized in Tables 4 and 11, respectively. These data can also be found in Tables 22 and 23 of Gdowski's degradation mode survey, respectively [G. E. Gdowski, "Survey of Degradation Modes of Four Nickel-Chromium-Molybdenum Alloys," UCRL-ID-108330, March, 1991, pp. 30-31]. Specific points used to generate Table 12 are in bold-face type. In the case of localized corrosion at $340 \mathrm{mV}$ vs. SHE, it is assumed that the penetration rates are similar to those observed for Alloy C-22 in simulated crevice solutions (accelerated passive corrosion in $10 \mathrm{wt} . \% \mathrm{FeCl}_{3}$ ). In the case of localized corrosion at $640 \mathrm{mV}$ vs. SHE, it is assumed that the penetration rates are similar to those observed for Alloy 625 (active crevice in $10 \mathrm{wt} . \% \mathrm{FeCl}_{3}$ and and active pitting corrosion in "green death" solution). The apparent activation energy is assumed to be $20 \mathrm{kcal} / \mathrm{mol}$, which is close to that observed for many chemical reactions. Note the rapid wall penetration at high applied potential (640 $\mathrm{mV}$ vs. NHE) and low $\mathrm{pH}(2.5)$.

Table 10a. Probabilities of Localized Corrosion Initiation on Alloy C-22 - Estimated CDF's.

\begin{tabular}{|c|c|c|c|}
\hline Case 1: $P=5 \%$ at $E_{\text {pass }} \& P=1 \%$ at $E_{\text {pass, low }}$ & Environment A & Environment B & Environment C \\
\hline PH & 2.5 & 2.5 & 5 to 7 \\
\hline $\bar{E}(\mathrm{mV}$ vs. SHE) & 340 & 640 & 340 \\
\hline$\beta$ at $25^{\circ} \mathrm{C}$ & $8.05 \times 10^{-3}$ & $8.05 \times 10^{-3}$ & $8.05 \times 10^{-3}$ \\
\hline$\beta$ at $50^{\circ} \mathrm{C}$ & $8.05 \times 10^{-3}$ & $8.05 \times 10^{-3}$ & $8.05 \times 10^{-3}$ \\
\hline$\beta$ at $100^{\circ} \mathrm{C}$ & $8.05 \times 10^{-3}$ & $8.05 \times 10^{-3}$ & $8.05 \times 10^{-3}$ \\
\hline $\mathrm{P}$ at $25^{\circ} \mathrm{C}$ & 0.0368 & 0.4123 & 0.0074 \\
\hline $\mathrm{P}$ at $50^{\circ} \mathrm{C}$ & 0.0824 & 0.9221 & 0.0165 \\
\hline $\mathrm{P}$ at $100^{\circ} \mathrm{C}$ & 0.1843 & 2.0625 & 0.0368 \\
\hline Case $2: \mathrm{P}=50 \%$ at $\mathrm{E}_{\text {pass }} \& \mathrm{P}=5 \%$ at $\mathrm{E}_{\text {pass, low }}$ & Environment A & Environment B & Environment C \\
\hline $\mathrm{pH}$ & 2.5 & 2.5 & 5 to 7 \\
\hline E (mV vs. SHE) & 340 & 640 & 340 \\
\hline$\beta$ at $25^{\circ} \mathrm{C}$ & $1.15 \times 10^{-2}$ & $1.15 \times 10^{-2}$ & $1.15 \times 10^{-2}$ \\
\hline$\beta$ at $50^{\circ} \mathrm{C}$ & $1.15 \times 10^{-2}$ & $1.15 \times 10^{-2}$ & $1.15 \times 10^{-2}$ \\
\hline$\beta$ at $100^{\circ} \mathrm{C}$ & $1.15 \times 10^{-2}$ & $1.15 \times 10^{-2}$ & $1.15 \times 10^{-2}$ \\
\hline $\mathrm{P}$ at $25^{\circ} \mathrm{C}$ & 0.0449 & 1.4148 & 0.0045 \\
\hline $\mathrm{P}$ at $50^{\circ} \mathrm{C}$ & 0.1419 & 4.4684 & 0.0142 \\
\hline $\mathrm{P}$ at $100^{\circ} \mathrm{C}$ & 0.4480 & 14.1120 & 0.0449 \\
\hline Case 3: $P=50 \%$ at $E_{\text {pass }} \& P=1 \%$ at $E_{\text {pass, low }}$ & Environment A & Environment B & Environment $\mathbf{C}$ \\
\hline $\mathrm{pH}$ & 2.5 & 2.5 & 5 to 7 \\
\hline $\mathrm{E}$ (mV vs. SHE) & 340 & 640 & 340 \\
\hline$\beta$ at $25^{\circ} \mathrm{C}$ & $7.82 \times 10^{-3}$ & $7.82 \times 10^{-3}$ & $7.82 \times 10^{-3}$ \\
\hline$\beta$ at $50^{\circ} \mathrm{C}$ & $7.82 \times 10^{-3}$ & $7.82 \times 10^{-3}$ & $7.82 \times 10^{-3}$ \\
\hline$\beta$ at $100^{\circ} \mathrm{C}$ & $7.82 \times 10^{-3}$ & $7.82 \times 10^{-3}$ & $7.82 \times 10^{-3}$ \\
\hline $\mathrm{P}$ at $25^{\circ} \mathrm{C}$ & 0.0424 & 0.4427 & 0.0089 \\
\hline P at $50^{\circ} \mathrm{C}$ & 0.0927 & 0.9678 & 0.0194 \\
\hline $\mathrm{P}$ at $100^{\circ} \mathrm{C}$ & 0.2026 & 2.1154 & 0.0424 \\
\hline
\end{tabular}


Table 10b. Estimated CDF Probabilities (\%) for Initiation of Localized Corrosion on Alloy C-22 During Dripping - Based on Table 10a (above) - Aqueous phase (dripping) required for initiation.

\begin{tabular}{|l|c|c|c|c|c|c|c|c|c|}
\hline Percentile (\%) & $\mathrm{A} / 25^{\circ} \mathrm{C}$ & $\mathrm{A} / 50^{\circ} \mathrm{C}$ & $\mathrm{A} / 100^{\circ} \mathrm{C}$ & $\mathrm{B} / 25^{\circ} \mathrm{C}$ & $\mathrm{B} / 50^{\circ} \mathrm{C}$ & $\mathrm{B} / 100^{\circ} \mathrm{C}$ & $\mathrm{C} / 25^{\circ} \mathrm{C}$ & $\mathrm{C} / 50^{\circ} \mathrm{C}$ & $\mathrm{C} / 100^{\circ} \mathrm{C}$ \\
\hline 1 & 0.0368 & 0.0824 & 0.1843 & 0.4123 & 0.9221 & 2.0625 & 0.0045 & 0.0142 & 0.0368 \\
\hline 50 & 0.0424 & 0.0927 & 0.2026 & 0.4427 & 0.9678 & 2.1154 & 0.0074 & 0.0165 & 0.0424 \\
\hline 99 & 0.0449 & 0.1419 & 0.4480 & 1.4148 & 4.4684 & 14.1120 & 0.0089 & 0.0194 & 0.0449 \\
\hline
\end{tabular}

Table 11. Penetration Rates for Active Localized Corrosion of Alloy 625 (no $W$ )-

Not Applicable for Alloy C-22 (contains W) - Observations Provided for Illustration and Contrast.

\begin{tabular}{|l|l|l|l|}
\hline Crevice Corrosion & Crevice Corrosion & Pitting Corrosion & Pitting Corrosion \\
\hline $25^{\circ} \mathrm{C}$ & $50^{\circ} \mathrm{C}$ & $25^{\circ} \mathrm{C}$ & $102{ }^{\circ} \mathrm{C}$ \\
\hline 10 wt. $\% \mathrm{FeCl}_{3}$ & $10 \mathrm{wt} . \% \mathrm{FeCl}_{3}$ & 7 vol. $\% \mathrm{H}_{2} \mathrm{SO}_{4}+$ & 7 vol. $\% \mathrm{H}_{2} \mathrm{SO}_{4}+$ \\
& & 3 vol. $\% \mathrm{HCl}+$ & 3 vol. $\% \mathrm{HCl}+$ \\
& & 1 wt. $\% \mathrm{FeCl}_{3}+$ & 1 wt. \% $\mathrm{FeCl}_{3}+$ \\
& & 1 wt. $\% \mathrm{CuCl}_{2}$ & 1 wt. \% $\mathrm{CuCl}_{2}$ \\
\hline $38.1 \mathrm{microns} / \mathrm{yr}$ & 3,150 microns/yr & 7.62 microns/yr & $48,060 \mathrm{microns} / \mathrm{yr}$ \\
\hline
\end{tabular}

Table 12. Penetration Rates for Active Localized Corrosion of Alloy 625 (no W) -

Not Applicable for Alloy C-22 (contains W) - CDF's for Parameters in Rate Expression.

\begin{tabular}{|c|c|c|c|c|c|c|c|}
\hline $\mathrm{pH}=2.5$ & & & & & & & \\
\hline \multicolumn{8}{|l|}{$E=340 \mathrm{mV}$} \\
\hline Percentile & $\mathrm{n}$ & $\mathrm{k}($ for $n=1)$ & Ea & $\mathrm{Q}$ & $\begin{array}{c}\text { Depth } \\
\left(1 \mathrm{yr} ; 25^{\circ} \mathrm{C} ; \mathrm{n}=1\right)\end{array}$ & $\begin{array}{c}\text { Depth } \\
\left(1 \mathrm{yr} ; 75^{\circ} \mathrm{C} ; \mathrm{n}=1\right)\end{array}$ & $\begin{array}{c}\text { Depth } \\
\left(1000 \mathrm{yr} ; 60^{\circ} \mathrm{C} ; \mathrm{n}=1\right)\end{array}$ \\
\hline$\%$ & none & microns/yr & $\mathrm{cal} / \mathrm{mol}$ & $\mathrm{K}$ & microns & microns & $\mathrm{cm}$ \\
\hline 0 & 0 & $5.07 \times 10^{12}$ & 5000 & 2500 & 0.01 & 1.7 & 0.0461 \\
\hline 1 & 0.1 & $7.99 \times 10^{12}$ & 10000 & 5000 & 0.02 & 2.6 & 0.0726 \\
\hline 5 & 0.3 & $1.26 \times 10^{13}$ & 15000 & 7500 & 0.03 & 4.2 & 0.1148 \\
\hline 50 & 0.5 & $3.83 \times 10^{13}$ & 20000 & 10000 & 0.10 & 12.7 & 0.3481 \\
\hline 95 & 0.7 & $1.16 \times 10^{14}$ & 25000 & 12500 & 0.31 & 38.5 & 1.0550 \\
\hline 99 & 0.9 & $9.37 \times 10^{14}$ & 30000 & 15000 & 2.50 & 310.4 & 8.5056 \\
\hline 100 & 1 & $7.08 \times 10^{15}$ & 35000 & 17500 & 18.89 & 2345.1 & 64.2713 \\
\hline \multicolumn{8}{|l|}{$\mathrm{pH}=2.5$} \\
\hline \multicolumn{8}{|l|}{$E=640 \mathrm{mV}$} \\
\hline Percentile & $\mathrm{n}$ & $\mathrm{k}($ for $\mathrm{n}=1)$ & Ea & $\mathrm{Q}$ & $\begin{array}{c}\text { Depth } \\
\left(1 \mathrm{yr} ; 50^{\circ} \mathrm{C} ; \mathrm{n}=1\right)\end{array}$ & $\begin{array}{c}\text { Depth } \\
\left(1 \mathrm{yr} ; 102^{\circ} \mathrm{C} ; \mathrm{n}=1\right)\end{array}$ & $\begin{array}{c}\text { Depth } \\
\left(1000 \mathrm{yr} ; 60^{\circ} \mathrm{C} ; \mathrm{n}=1\right)\end{array}$ \\
\hline$\%$ & none & microns/yr & $\mathrm{cal} / \mathrm{mol}$ & $\mathrm{K}$ & microns & microns & $\mathrm{cm}$ \\
\hline 0 & 0 & $2.42 \times 10^{15}$ & 5000 & 2500 & 87 & 6360 & 22 \\
\hline 1 & 0.1 & $3.82 \times 10^{15}$ & 10000 & 5000 & 137 & 10018 & 35 \\
\hline 5 & 0.3 & $6.04 \times 10^{15}$ & 15000 & 7500 & 217 & 15855 & 55 \\
\hline 50 & 0.5 & $1.83 \times 10^{16}$ & 20000 & 10000 & 657 & 48060 & 166 \\
\hline 95 & 0.7 & $5.55 \times 10^{16}$ & 25000 & 12500 & 1990 & 145677 & 504 \\
\hline 99 & 0.9 & $8.79 \times 10^{16}$ & 30000 & 15000 & 3150 & 230555 & 798 \\
\hline 100 & 1 & $6.64 \times 10^{17}$ & 35000 & 17500 & 23803 & 1742155 & 6031 \\
\hline
\end{tabular}


Table 12 (cont'd.). Penetration Rates for Active Localized Corrosion of Alloy 625 (no W) Not Applicable for Alloy $C-22$ (contains $W$ ) - CDF's for Parameters in Rate Expression.

\begin{tabular}{|c|c|c|c|c|c|c|c|}
\hline $\mathbf{p H = 3 - 1 0}$ & & & & & & & \\
\hline $\mathbf{E}=\mathbf{3 4 0} \mathbf{~ m V}$ & & & & & & & \\
\hline Percentile & $\mathrm{n}$ & $\mathrm{k}$ (for $\mathrm{n}=1)$ & $\mathrm{Ea}$ & $\mathrm{Q}$ & $\begin{array}{c}\text { Depth } \\
\left(1 \mathrm{yr} ; 25^{\circ} \mathrm{C} ; \mathrm{n}=1\right)\end{array}$ & $\begin{array}{c}\text { Depth } \\
\left(1 \mathrm{yr} ; 75^{\circ} \mathrm{C} ; \mathrm{n}=1\right)\end{array}$ & $\begin{array}{c}\text { Depth } \\
\left(1000 \mathrm{yr} ; 60^{\circ} \mathrm{C} ; \mathrm{n}=1\right)\end{array}$ \\
\hline$\%$ & none & microns/yr & $\mathrm{cal} / \mathrm{mol}$ & $\mathrm{K}$ & microns & microns & $\mathrm{cm}$ \\
\hline 0 & 0 & $5.07 \times 10^{12}$ & 5000 & 2500 & 0.01 & 1.7 & 0.0461 \\
\hline 1 & 0.1 & $7.99 \times 10^{12}$ & 10000 & 5000 & 0.02 & 2.6 & 0.0726 \\
\hline 5 & 0.3 & $1.26 \times 10^{13}$ & 15000 & 7500 & 0.03 & 4.2 & 0.1148 \\
\hline 50 & 0.5 & $\mathbf{3 . 8 3 \times 1 0}$ & 20000 & 10000 & 0.10 & $\mathbf{1 2 . 7}$ & 0.3481 \\
\hline 95 & 0.7 & $1.16 \times 10^{14}$ & 25000 & 12500 & 0.31 & 38.5 & 1.0550 \\
\hline 99 & 0.9 & $\mathbf{9 . 3 7 \times 1 0}$ & 30000 & 15000 & $\mathbf{2 . 5 0}$ & 310.4 & $\mathbf{8 . 5 0 5 6}$ \\
\hline 100 & 1 & $7.08 \times 10^{15}$ & 35000 & 17500 & 18.89 & 2345.1 & 64.2713 \\
\hline
\end{tabular}

In regard to pit penetration rates, it must be noted that the current elicitation does not deal with the issue of "stiffling" which leads to the death or a propagating pit. This very important effect has been given emphasis Prof. Scully's presentations and discussion [J. R. Scully, "Appendix D, Elicitation Interview Summaries," Waste Package Degradation Expert Elicitation Project Final Report, K. J. Coppersmith, R. C. Perman, M. Pendleton, J. L. Younker, Civilian Radioactive Waste Management System Management and Operating Contractor, Geomatrix Consultants, San Francisco, CA, August 15, 1997, pp. JS 1-30]. In principle, a pit will cease to grow (die) if the depth becomes so great that the current density at the base of the pit falls below the passive current density. The importance of "stifling" has also been pointed out by Marsh [G. P. Marsh, K. J. Taylor, Z Sooi, "The Kinetics of Pitting Corrosion of Carbon Steel," SKB Technical Report 88-09, Swedish Nuclear Fuel and Waste Management Company (SKB), Box 5864, S10248 , Stockholm, 1988, 39 p.]. In the case of pit propagation in carbon steel, Marsh gives the following criterion based upon the passive current density and the diffusive flux of dissolved oxygen:

$$
\frac{i_{p a s s}}{4 F} \leq-\left.D \frac{\partial C(x, t)}{\partial x}\right|_{x=0}
$$

where $i_{\text {pass }}$ is the passive current density at the base of the pit, $F$ is Faraday's constant, $D$ and $C$ are the diffusivity and concentration of dissolved oxygen, respectively, $\mathrm{x}$ is the distance into the pit from the mouth of the pit, and $t$ is time. It was noted that careful measurements of $i_{\text {pass }}$ are required for any theoretical analysis. The critical concentration gradient across the pit is estimated to be:

$$
-\left.\frac{\Delta C}{\Delta x}\right|_{\text {critical }} \geq \frac{i_{\text {pass }}}{4 F D}
$$

Alternatively, given a maximum possible differential concentration of dissolved oxygen, the maximum possible pit depth at stifling (death) can be calculated.

$$
\Delta x \leq-\frac{4 F D \Delta C}{i_{\text {pass }}}
$$

The largest critical pit depth occurs when the dissolved oxygen is saturated at the mouth of the pit, and entirely depleted at the base of the pit $\left(\Delta \mathrm{C} \sim 0-\mathrm{C}_{\text {sat }}\right)$. 


$$
\Delta x \leq \frac{4 F D C_{s a t}}{i_{p a s s}}
$$

Estimates of the critical pit depth, based upon the diffusion-limited current density associated with oxygen reduction are summarized in Table 13. The following assumptions were made: (a) $\mathrm{F}=9.64846 \times 10^{4}$ C/equiv; (b) $\mathrm{D} \sim 10^{-5} \mathrm{~cm}^{2} / \mathrm{sec}$; and (c) $\mathrm{i}_{\text {pass }}=4 \times 10^{-6} \mathrm{~A} / \mathrm{cm}^{2}$. The oxygen solubilites were given by Dr. Peter Andresen [P. L. Andresen, "Assessment of Corrosion Rate Properties for the Hastelloy C-22 Inner Barrier, An Environment for Waste Packages, Background Information for Consideration," General Electric Research Center, February 27, 1998, p. 12].

Table 13. Pit Stifling Criterion Based on Flux of Dissolved Oxygen at $25^{\circ} \mathrm{C}$.

\begin{tabular}{|l|l|l|l|}
\hline $\mathrm{NaCl}($ wt. \%) & $\mathrm{O}_{2}(\mathrm{ppm})$ & $\mathrm{O}_{2}\left(\mathrm{~mol} / \mathrm{cm}^{3}\right)$ & $\Delta \mathrm{x}(\mathrm{cm})$ \\
\hline 0 & 8.2 & $2.56 \times 10^{-7}$ & 0.25 \\
\hline 3.5 & 6.8 & $2.13 \times 10^{-7}$ & 0.20 \\
\hline 5 & 6.0 & $1.88 \times 10^{-7}$ & 0.18 \\
\hline 16 & 2.9 & $9.06 \times 10^{-8}$ & 0.09 \\
\hline Satd. & $<2.0$ & $<6.25 \times 10^{-8}$ & $<0.06$ \\
\hline
\end{tabular}

An alternative criterion for pit stifling can be formulated based upon the diffusion-limited flux of dissolved metal inside the pit. In the case of a multicomponent material such as Alloy C-22, the modified stifling criterion can be expressed in terms of the total concentration gradient of the $\mathrm{i}$-th dissolved metal (Fe, Ni, Cr, Mo or W):

$$
\left.\frac{\Delta C_{i}}{\Delta x}\right|_{\text {criical }} \geq \frac{f_{i}}{n_{i}} \frac{i_{\text {pass }}}{F D_{i}}
$$

where $C_{i}$ is the total concentration of the $\mathrm{i}$-th dissolved metal; $\mathrm{x}$ is the distance from the mouth of the pit; $\mathrm{f}_{\mathrm{i}}$ is the mole fraction of the passive current producing the $\mathrm{i}$-th dissolved metal, $\mathrm{i}_{\text {pass }}$ is the passive current density at the base of the pit; $n_{i}$ is the the number of electrons involved in the anodic dissolution of the $i$-th dissolved metal; $\mathrm{F}$ is Faraday's constant; and $\mathrm{D}_{\mathrm{i}}$ is the apparent or overall diffusivity of the $\mathrm{i}$-th dissolved metal. In order to transport dissolved metal out of the pit without accumulation, precipitation, passivation, and stifling, this critical concentration gradient must be maintained. If one assumes (a) $f_{i}=$ 0.01 , (b) $\mathrm{i}_{\text {pass }}=4 \times 10^{-6} \mathrm{~A} / \mathrm{cm}^{2}$, (c) $\mathrm{n}_{\mathrm{i}}=6$, (d) $\mathrm{F}=9.64846 \times 10^{4} \mathrm{C} /$ equiv, (e) $\mathrm{D}_{\mathrm{i}} \sim 10^{-5} \mathrm{~cm}^{2} / \mathrm{sec}$ and (f) $\Delta \mathrm{x}=2$ $\mathrm{cm}$, the critical differential concentration, $\Delta \mathrm{C}_{\mathrm{i}}$, is estimated to be $1.38 \times 10^{-8} \mathrm{~mol} / \mathrm{g}\left(1.38 \times 10^{-5} \mathrm{~mol} / \mathrm{kg}\right)$. Note that the solubility of $\mathrm{WO}_{3}$ is only $\sim 10^{-10} \mathrm{~mol} / \mathrm{kg}$ at $\mathrm{pH} \sim 2$. If any dissolved species at the base of the pit has a solubility less than this limiting value, the pit will die before wall penetration is achieved. Alternatively, given a maximum possible differential concentration, the maximum possible pit depth at stifling (death) can be calculated.

$$
\Delta x \leq \frac{n_{i} F D_{i} \Delta C_{i}}{f_{i} i_{p a s s}}
$$

The largest differential concentration and the largest critical pit depth occur when the solution at the base of the pit is saturated and when the concentration at the mouth of the pit is zero. 
$\Delta x \leq \frac{n_{i} F D_{i} C_{\text {sat }, i}}{f_{i} i_{\text {pass }}}$

The solubilities of various oxides and hydroxides believed to be formed during dissolution of Alloy C-22 are given by Pourbaix and are shown in Table 14 [M. Pourbaix, Atlas of Electrochemical Equilibria in Aqueous Solutions, English Translation by J. A. Franklin, Pergamon Press, New York, NY; Cebelcor, Brussels, Belgium, 1966, 644 p]. From the solubility vs. pH curves given by Pourbaix, it appears that the following empirical relationship is obeyed over limited ranges of $\mathrm{pH}$ :

$\log \left[C_{s a t, i}\right]=m_{i} \times[p H]+b_{i}$

Where $C_{\text {sat, } i}$ is the concentration of the $i$-th dissolved metal at saturation, $m_{i}$ is the slope and $b_{i}$ is the intercept. Values of the slope and intercept were estimated from the curves of Pourbaix and are also given in Table 14. This abstracted model for solubility was used to estimate the logarithims of solubilities given in Table 15, and the solubilities $(\mathrm{mol} / \mathrm{kg})$ given in Table 16.

Based upon the estimated solubilites given in Table 15, the critical pit depths were calculated and are given in Tables 17 and 18. Ranges of $\mathrm{pH}$ where localized corrosion is stiffled by a particular filmforming compound are in bold face type. The pit depth is limited to a different extent by each oxide or hydroxide. At low $\mathrm{pH}, \mathrm{MoO}_{3}$ and $\mathrm{WO}_{3}$ appear to be primarily responsible for the superior corrosion performance of Alloy C-22. Based upon this calculation, one would expect the localized corrosion of Alloy $\mathrm{C}-22$ to be stifled over the entire range of $\mathrm{pH}$, extending from -1 to 10 . This is consistent with observations in acidic media of interest (simulated crevice solution of $10 \mathrm{wt} . \% \mathrm{FeCl}_{3}$ ). There are unusual acidic environments where corrosion is known to occur. Both experience and calculation appear to indicate that pits should not propagate in Alloy C-22 during exposure to crevice conditions.

Clearly, the rates for penetration of the CRM must reflect the stifling of localized attack by Mo- and Wbased compounds. This is consistent with a consensus reached by the majority of the Expert Elicitation Panel members during a conference call at noon on Friday, February 27, 1998. Published experimental data obtained with simulated crevice solutions ( $10 \mathrm{wt} . \% \mathrm{FeCl}_{3}$ at 25,50 and $75^{\circ} \mathrm{C}$ ) and experimental data from tests with crevice samples exposed to simulated acidified J-13 water (SAW) for 1 year (long term tests at LLNL) both indicate penetration by passive corrosion through a protective film. Observed penetration rates of Alloy C-22 show that the corrosion of Alloy C-22 in anticipated crevice solutions is due to passive dissolution, not catastrophic breakdown of the passive film. In the opinion of this member of the Expert Elicitation Panel, it is therefore appropriate to use the previously discussed correlation of experimental data to estimate penetration rates in the crevice. Such rates are believed to account for the stifling effect of $\mathrm{Mo}_{3}$ and $\mathrm{WO}_{3}$. Uncertainties should be treated in the same manner as in the case of passive corrosion rates. This is believed to be more or less consistent with the insight of other members of the Expert Elicitation Panel. Kevin Coppersmith of Geomatrix posed the following question: "What is the rate of localized corrosion on the Alloy C-22 inner barrier once it initiates." Dr. Andresen replied [February 28, 1998]: "The approach adopted by Joe Farmer, e.g., as expressed in his elicitation (earlier version), appear entirely adequate based on our current state of knowledge. Caution must be exercised in determining how long to continue to use a given corrosion rate because, as the waste backage cools even slightly, there is a very strong liklihood that localized corrosion will cease. Because the critical temperature for crevice corrosion is very high for C-22, the probability of initiating (and sustaining) localized corrosion is much lower even at $90^{\circ} \mathrm{C}$ than $100^{\circ} \mathrm{C}$." Please note that we distinguish between "stifled passive corrosion in a crevice" and "classical active crevice corrosion." Dr. Shoesmith replied 
[March 2, 1998]: "The rate should be scaled according to the B values (and their uncertainties) used by Farmer. A similar activation energy term to that used by Farmer (should be) included. This is Localized Corrosion Model III as presented by Lee in Washington." Boths Drs. Andresen and Shoesmith are internationally renowned for their unusualy high level of expertise in the field of corrosion of nuclear systems. This member believes that such opinions should be heavily weighted. The correlation presented to Drs. Andresen and Shoesmith has been used as the basis of generating the penetration rates for the localized corrosion of Alloy C-22 in Table 19, which are believed to reflect stifling (as per guidance of February 27,1998 ). In the case of $1000 \mathrm{X} \mathrm{J}-13$, it is assumed that the localized environment can be represented by the following inputs to the correlation, which are within (or close to) the bounds of the correlated data: $\mathrm{NaCl}=1.2$ wt. \%; $\mathrm{FeCl}_{3}=1 \mathrm{wt} . \% ; \mathrm{pH}=1.92$. In the case of saturated $\mathrm{J}-13$, is is assumed that the localized environment can be represented by the following inputs to the correlation, which are within (or close to) the bounds of the correlated data: $\mathrm{NaCl}=1.2 \mathrm{wt} \% ; \mathrm{FeCl}_{3}=10 \mathrm{wt}$. \%; pH $=0.7$. In both cases, the $\mathrm{NaCl}$ concentration is based upon the "equivalent $\mathrm{NaCl}$ concentration" in $1000 \mathrm{X}$ J-13. At $1000 \mathrm{X} \mathrm{J}-13(1.2 \mathrm{wt}$. $\% \mathrm{NaCl})$, the effect of crevice corrosion is accounted for by the assumed presence of 1 wt. \% FeCl3 (comparable to $\mathrm{NaCl}$ concentration), which would lower the $\mathrm{pH}$ to about 1.92 at $25^{\circ} \mathrm{C}$ (see Table 2). Under saturated conditions, it is assumed that much higher concentrations of chloride will exist at the mouth of the crevice, enabling the $\mathrm{FeCl}_{3}$ inside the crevice to increase to $10 \mathrm{wt}$. $\%$, which is comparable to the simulated crevice solution used for accelerated testing by Asphahani (see Table 4, Haynes, 1987). From the data given in Table 2, it is believed that the $\mathrm{pH}$ of an aqueous solution with 10 wt. $\% \mathrm{FeCl}_{3}$ is approximately 0.7 .

In regard to the estimated rates given in Table 19, it is assumed that the same penetration rate will be experienced at both 340 and $640 \mathrm{mV}$ vs. SHE. This is comparable to assuming that the passive current density is independent of potential from 340 to $640 \mathrm{mV}$ vs. SHE, which is observed experimentally during some cyclic polarization measurments [quality data of Dr. Ajit Roy, August 28, 1998, 5 wt. \% $\left.\mathrm{NaCl}, \mathrm{pH} 2.53,90^{\circ} \mathrm{C}, 0.17 \mathrm{mV} / \mathrm{sec}\right]$. It is further assumed that the $\mathrm{pH}$ inside the crevice (or pit) is dominated by local hydrolysis reactions, which is assumed to be due to the concentration of $\mathrm{FeCl}_{3}$. Therefore, Table 19 is assumed to apply for Environments A, B and C (see Table 10a for details of assumed environments). 
Table 14. Solubilities Given by Pourbaix for Various Compounds

Responsible for Passivation of Alloy C-22.

\begin{tabular}{|c|c|c|c|c|c|c|c|}
\hline Film Species & $\log \left(\mathrm{C}_{\mathrm{i}, 1}\right)$ & $\mathrm{pH}_{1}$ & $\log \left(\mathrm{C}_{\mathrm{i}, 2}\right)$ & $\mathrm{pH}_{2}$ & $\mathrm{~m}_{\mathrm{i}}$ & $\mathrm{b}_{\mathrm{i}}$ & Ref. \\
\hline $\mathrm{Fe}(\mathrm{OH})_{2}$ & -2.5 & 8 & -6.5 & 10 & -2 & 13.5 & Pourbaix p. 311 \\
\hline $\mathrm{Fe}(\mathrm{OII})_{3}$ & -1 & 2 & -3 & 3 & -2.00 & 3.00 & Pourbaix p. 311 \\
\hline $\mathrm{Fe}_{2} \mathrm{O}_{3}$ & -1 & 0 & -8 & 2.5 & -2.80 & -1.00 & Pourbaix p. 311 \\
\hline $\mathrm{Ni}(\mathrm{OH})_{2}$ & -1 & 6.5 & -8 & 10 & -2.00 & 12.00 & Pourbaix p. 336 \\
\hline $\mathrm{Cr}(\mathrm{OH})_{3}$ & -3 & 2.5 & -12 & 5.7 & -2.81 & 4.03 & Pourbaix p. 268 \\
\hline $\mathrm{Cr}_{2} \mathrm{O}_{3}$ & -3 & 3.7 & -9.5 & 6 & -2.83 & 7.46 & Pourbaix p. 268 \\
\hline $\mathrm{Cr}(\mathrm{OH})_{3}-\mathrm{nH}_{2} \mathrm{O}$ & 0 & 4 & -4 & 6 & -2.00 & 8.00 & Pourbaix p. 268 \\
\hline $\mathrm{MoO}_{3}$ & -3.7 & 0 & 1 & 4.7 & 1.00 & -3.70 & Pourbaix p. 276 \\
\hline $\mathrm{WO}_{3}$ & -8 & 3 & 0 & 7 & 2.00 & -14.00 & Pourbaix p. 283 \\
\hline
\end{tabular}

Table 15. Predicted Logarithims of Solubilities at Various pH Values-

Based on Slopes and Intercepts in Table 14.

\begin{tabular}{|c|c|c|c|c|c|c|c|c|c|}
\hline $\mathrm{pH}$ & $\mathrm{Fe}(\mathrm{OH})_{2}$ & $\mathrm{Fe}(\mathrm{OH})_{3}$ & $\mathrm{Fe}_{2} \mathrm{O}_{3}$ & $\mathrm{Ni}(\mathrm{OH})_{2}$ & $\mathrm{Cr}(\mathrm{OH})_{3}$ & $\mathrm{Cr}_{2} \mathrm{O}_{3}$ & $\mathrm{Cr}(\mathrm{OH})_{3}-\mathrm{nH}_{2} \mathrm{O}$ & $\mathrm{MoO}_{3}$ & $\mathrm{WO}_{3}$ \\
\hline-1 & 15.50 & 5.00 & 1.80 & 14.00 & 6.84 & 10.29 & 10.00 & -4.70 & -16.00 \\
\hline 0 & 13.50 & 3.00 & -1.00 & 12.00 & 4.03 & 7.46 & 8.00 & -3.70 & -14.00 \\
\hline 1 & 11.50 & 1.00 & -3.80 & 10.00 & 1.22 & 4.63 & 6.00 & -2.70 & -12.00 \\
\hline 2 & 9.50 & -1.00 & -6.60 & 8.00 & -1.59 & 1.80 & 4.00 & -1.70 & -10.00 \\
\hline 3 & 7.50 & -3.00 & -9.40 & 6.00 & -4.40 & -1.03 & 2.00 & -0.70 & -8.00 \\
\hline 4 & 5.50 & -5.00 & -12.20 & 4.00 & -7.21 & -3.86 & 0.00 & 0.30 & -6.00 \\
\hline 5 & 3.50 & -7.00 & -15.00 & 2.00 & -10.02 & -6.69 & -2.00 & 1.30 & -4.00 \\
\hline 6 & 1.50 & -9.00 & -17.80 & 0.00 & -12.83 & -9.52 & -4.00 & 2.30 & -2.00 \\
\hline 7 & -0.50 & -11.00 & -20.60 & -2.00 & -15.64 & -12.35 & -6.00 & 3.30 & 0.00 \\
\hline 8 & -2.50 & -13.00 & -23.40 & -4.00 & -18.45 & -15.18 & -8.00 & 4.30 & 2.00 \\
\hline 9 & -4.50 & -15.00 & -26.20 & -6.00 & -21.26 & -18.01 & -10.00 & 5.30 & 4.00 \\
\hline 10 & -6.50 & -17.00 & -29.00 & -8.00 & -24.07 & -20.84 & -12.00 & 6.30 & 6.00 \\
\hline
\end{tabular}

Table 16. Alloy Composition Assumed for Congruent Dissolution of Alloy C-22 -

Required by Modified Pit Stifling Criterion.

\begin{tabular}{|c|c|c|c|c|}
\hline Component & wt. fract. & MW & mol/gram & mol fract. $\left(f_{i}\right)$ \\
\hline $\mathrm{Fe}$ & 0.04 & 55.847 & 0.000716243 & 0.043879444 \\
\hline $\mathrm{Co}$ & 0.02 & 58.9332 & 0.000339367 & 0.020790788 \\
\hline $\mathrm{Cr}$ & 0.21 & 51.996 & 0.004038772 & 0.24742885 \\
\hline $\mathrm{W}$ & 0.03 & 183.85 & 0.000163177 & 0.009996745 \\
\hline $\mathrm{Mo}$ & 0.13 & 95.94 & 0.001355014 & 0.083012714 \\
\hline $\mathrm{Ni}$ & 0.57 & 58.7 & 0.009710392 & 0.594891456 \\
\hline Total & 1 & & & 1 \\
\hline
\end{tabular}


Table 17. Maximum Possible Pit Depths $(\Delta x / \mathrm{cm})$ in Alloy C-22 Predicted with Modified Pit Stifling CriterionAssuming $\triangle C \sim 100 \% C_{\text {sat }} \& i_{\text {pass }} \sim 4 \mu \mathrm{A} / \mathrm{cm}^{2}$.

\begin{tabular}{|c|c|c|c|c|c|c|c|c|c|}
\hline $\mathrm{pH}$ & $\mathrm{Fe}(\mathrm{OH})_{2}$ & $\mathrm{Fe}(\mathrm{OH})_{3}$ & $\mathrm{Fe}_{2} \mathrm{O}_{3}$ & $\mathrm{Ni}(\mathrm{OH})_{2}$ & $\mathrm{Cr}(\mathrm{OH})_{3}$ & $\mathrm{Cr}_{2} \mathrm{O}_{3}$ & $\mathrm{Cr}(\mathrm{OH})_{3}-\mathrm{nH}_{2} \mathrm{O}$ & $\mathrm{MoO}_{3}$ & $\mathrm{WO}_{3}$ \\
\hline-1 & $3.48 \times 10^{19}$ & $1.65 \times 10^{9}$ & $1.04 \times 10^{6}$ & $8.11 \times 10^{16}$ & $2.02 \times 10^{10}$ & $5.70 \times 10^{13}$ & $2.92 \times 10^{13}$ & $3.48 \times 10^{-1}$ & $1.45 \times 10^{-11}$ \\
\hline 0 & $3.48 \times 10^{17}$ & $1.65 \times 10^{\prime}$ & $1.65 \times 10^{3}$ & $8.11 \times 10^{14}$ & $3.13 \times 10^{\prime}$ & $8.43 \times 10^{10}$ & $2.92 \times 10^{I I}$ & 3.48 & $1.45 \times 10^{-9}$ \\
\hline 1 & $3.48 \times 10^{15}$ & $1.65 \times 10^{5}$ & 2.61 & $8.11 \times 10^{12}$ & $4.85 \times 10^{4}$ & $1.25 \times 10^{8}$ & $2.92 \times 10^{9}$ & $3.48 \times 10^{1}$ & $1.45 \times 10^{-1}$ \\
\hline 2 & $3.48 \times 10^{13}$ & $1.65 \times 10^{3}$ & $4.14 \times 10^{-5}$ & $8.11 \times 10^{10}$ & $7.52 \times 10^{1}$ & $1.85 \times 10^{3}$ & $2.92 \times 10^{7}$ & $3.48 \times 10^{2}$ & $1.45 \times 10^{-5}$ \\
\hline 3 & $3.48 \times 10^{11}$ & $1.65 \times 10^{1}$ & $6.57 \times 10^{-6}$ & $8.11 \times 10^{8}$ & $1.16 \times 10^{-1}$ & $2.73 \times 10^{2}$ & $2.92 \times 10^{5}$ & $3.48 \times 10^{3}$ & $1.45 \times 10^{-3}$ \\
\hline 4 & $3.48 \times 10^{9}$ & $1.65 \times 10^{-1}$ & $1.04 \times 10^{-8}$ & $8.11 \times 10^{6}$ & $1.80 \times 10^{-4}$ & $4.04 \times 10^{-1}$ & $2.92 \times 10^{3}$ & $3.48 \times 10^{4}$ & $1.45 \times 10^{-1}$ \\
\hline 5 & $3.48 \times 10^{\prime}$ & $1.65 \times 10^{-3}$ & $1.65 \times 10^{-1 T}$ & $8.11 \times 10^{4}$ & $2.79 \times 10^{-7}$ & $5.97 \times 10^{-4}$ & $2.92 \times 10^{1}$ & $3.48 \times 10^{3}$ & $1.45 \times 10^{1}$ \\
\hline 6 & $3.48 \times 10^{5}$ & $1.65 \times 10^{-5}$ & $2.61 \times 10^{-14}$ & $8.11 \times 10^{2}$ & $4.33 \times 10^{-10}$ & $8.83 \times 10^{-7}$ & $2.92 \times 10^{-1}$ & $3.48 \times 10^{6}$ & $1.45 \times 10^{5}$ \\
\hline 7 & $3.48 \times 10^{3}$ & $1.65 \times 10^{-1}$ & $4.14 \times 10^{-17}$ & 8.11 & $6.70 \times 10^{-15}$ & $1.31 \times 10^{-9}$ & $2.92 \times 10^{-3}$ & $3.48 \times 10^{\prime}$ & $1.45 \times 10^{5}$ \\
\hline 8 & $3.48 \times 10^{1}$ & $1.65 \times 10^{-9}$ & $6.57 \times 10^{-20}$ & $8.11 \times 10-2$ & $1.04 \times 10^{-15}$ & $1.93 \times 10^{-12}$ & $2.92 \times 10^{-5}$ & $3.48 \times 10^{8}$ & $1.45 \times 10^{\prime}$ \\
\hline 9 & $3.48 \times 10^{-1}$ & $1.65 \times 10^{-11}$ & $1.04 \times 10^{-22}$ & $8.11 \times 10-4$ & $1.61 \times 10^{-18}$ & $2.86 \times 10^{-15}$ & $2.92 \times 10^{-7}$ & $3.48 \times 10^{9}$ & $1.45 \times 10^{9}$ \\
\hline 10 & $3.48 \times 10^{-3}$ & $1.65 \times 10^{-13}$ & $1.65 \times 10^{-25}$ & $8.11 \times 10-6$ & $2.49 \times 10^{-21}$ & $4.23 \times 10^{-18}$ & $2.92 \times 10^{-9}$ & $3.48 \times 10^{10}$ & $1.45 \times 10^{\mathrm{II}}$ \\
\hline
\end{tabular}

Note: Ranges of $\mathrm{pH}$ where localized corrosion is stiffled by a particular film-forming compound are in bold-face type. At low $\mathrm{pH}, \mathrm{MoO}_{3}$ and $\mathrm{WO}_{3}$ appear to be primarily responsible for the superior corrosion performance of Alloy C-22. Localized corrosion should be stiffled over the entire range of $p H$, extending from -1 to 10 . This is consistent with observation in most (but not all) acidic media. 
Table 18. Maximum Possible Pit Depths $(\Delta x / \mathrm{cm})$ in Alloy C-22 Predicted with Modified Pit Stifling CriterionAssuming $\Delta C \sim 10 \% C_{\text {sat }} \& i_{\text {pass }} \sim 4 \mu \mathrm{A} / \mathrm{cm}^{2}$.

\begin{tabular}{|c|c|c|c|c|c|c|c|c|c|}
\hline $\mathrm{pH}$ & $\mathrm{Fe}(\mathrm{OH})_{2}$ & $\mathrm{Fe}(\mathrm{OH})_{3}$ & $\mathrm{Fe}_{2} \mathrm{O}_{3}$ & $\mathrm{Ni}(\mathrm{OH})_{2}$ & $\mathrm{Cr}(\mathrm{OH})_{3}$ & $\mathrm{Cr}_{2} \mathrm{O}_{3}$ & $\mathrm{Cr}(\mathrm{OH})_{3}-\mathrm{nH}_{2} \mathrm{O}$ & $\mathrm{MoO}_{3}$ & $\mathrm{WO}_{3}$ \\
\hline-1 & $3.48 \times 10^{18}$ & $1.65 \times 10^{8}$ & $1.04 \times 10^{5}$ & $8.11 \times 10^{15}$ & $2.02 \times 10^{9}$ & $5.70 \times 10^{12}$ & $2.92 \times 10^{12}$ & $3.48 \times 10^{-2}$ & $1.45 \times 10^{-12}$ \\
\hline 0 & $3.48 \times 10^{16}$ & $1.65 \times 10^{6}$ & $1.65 \times 10^{2}$ & $8.11 \times 10^{15}$ & $3.13 \times 10^{6}$ & $8.43 \times 10^{9}$ & $2.92 \times 10^{10}$ & $3.48 \times 10^{-1}$ & $1.45 \times 10^{-10}$ \\
\hline 1 & $3.48 \times 10^{14}$ & $1.65 \times 10^{4}$ & $2.61 \times 10^{-1}$ & $8.11 \times 10^{11}$ & $4.85 \times 10^{5}$ & $1.25 \times 10^{\top}$ & $2.92 \times 10^{8}$ & 3.48 & $1.45 \times 10^{-8}$ \\
\hline 2 & $3.48 \times 10^{12}$ & $1.65 \times 10^{2}$ & $4.14 \times 10^{-4}$ & $8.11 \times 10^{9}$ & 7.52 & $1.85 \times 10^{4}$ & $2.92 \times 10^{6}$ & $3.48 \times 10^{\mathrm{T}}$ & $1.45 \times 10^{-6}$ \\
\hline 3 & $3.48 \times 10^{10}$ & 1.65 & $6.57 \times 10^{-7}$ & $8.11 \times 10^{7}$ & $1.16 \times 10^{-2}$ & $2.73 \times 10^{1}$ & $2.92 \times 10^{4}$ & $3.48 \times 10^{2}$ & $1.45 \times 10^{-4}$ \\
\hline 4 & $3.48 \times 10^{8}$ & $1.65 \times 10^{-2}$ & $1.04 \times 10^{-9}$ & $8.11 \times 10^{5}$ & $1.80 \times 10^{-5}$ & $4.04 \times 10^{-2}$ & $2.92 \times 10^{2}$ & $3.48 \times 10^{3}$ & $1.45 \times 10^{-2}$ \\
\hline 5 & $3.48 \times 10^{6}$ & $1.65 \times 10^{-4}$ & $1.65 \times 10^{-12}$ & $8.11 \times 10^{3}$ & $2.79 \times 10^{-8}$ & $5.97 \times 10^{-5}$ & 2.92 & $3.48 \times 10^{4}$ & 1.45 \\
\hline 6 & $3.48 \times 10^{4}$ & $1.65 \times 10^{-6}$ & $2.61 \times 10^{-15}$ & $8.11 \times 10^{1}$ & $4.33 \times 10^{-11}$ & $8.83 \times 10^{-8}$ & $2.92 \times 10^{-2}$ & $3.48 \times 10^{5}$ & $1.45 \times 10^{2}$ \\
\hline 7 & $3.48 \times 10^{2}$ & $1.65 \times 10^{-8}$ & $4.14 \times 10^{-18}$ & $8.11 \times 10^{-1}$ & $6.70 \times 10^{-14}$ & $1.31 \times 10^{-10}$ & $2.92 \times 10^{-4}$ & $3.48 \times 10^{6}$ & $1.45 \times 10^{4}$ \\
\hline 8 & 3.48 & $1.65 \times 10^{-10}$ & $6.57 \times 10^{-21}$ & $8.11 \times 10^{-5}$ & $1.04 \times 10^{-16}$ & $1.93 \times 10^{-15}$ & $2.92 \times 10^{-6}$ & $3.48 \times 10^{7}$ & $1.45 \times 10^{6}$ \\
\hline 9 & $3.48 \times 10^{-2}$ & $1.65 \times 10^{-12}$ & $1.04 \times 10^{-23}$ & $8.11 \times 10^{-5}$ & $1.61 \times 10^{-19}$ & $2.86 \times 10^{-16}$ & $2.92 \times 10^{-8}$ & $3.48 \times 10^{8}$ & $1.45 \times 10^{8}$ \\
\hline 10 & $3.48 \times 10^{-4}$ & $1.65 \times 10^{-14}$ & $1.65 \times 10^{-26}$ & $8.11 \times 10^{-7}$ & $2.49 \times 10^{-22}$ & $4.23 \times 10^{-19}$ & $2.92 \times 10^{-10}$ & $3.48 \times 10^{9}$ & $1.45 \times 10^{10}$ \\
\hline
\end{tabular}

Note: Ranges of $\mathrm{pH}$ where localized corrosion is stiffled by a particular film-forming compound are in bold-face type. At low $\mathrm{pH}, \mathrm{MoO}_{3}$ and $\mathrm{WO}_{3}$ appear to be primarily responsible for the superior corrosion performance of Alloy C-22. Localized corrosion should be stiffled over the entire range of $p H$, extending from -1 to 10 . This is consistent with observation in most (but not all) acidic media. 
Draft Rev. 6 - J. C. Farmer, LLNL, YMP WP Degradation, Expert Elicitation Panel, March 4, 1998

Table 19. Penetration Rates for Localized Corrosion of Alloy C-22, Estimated to Account for the Stifling Effect - 50 th Percentile Based on Multivariable Linear Regression Analysis of 6-Month Data from LTCTF, Published Haynes Data (Asphahani), and Converted Corrosion Currents from Cyclic Polarization (Roy).

\begin{tabular}{|c|c|c|c|c|c|c|}
\hline $\mathrm{J}-13 \mathrm{Concentration}$ & $1000 \mathrm{X}$ & $1000 \mathrm{X}$ & $1000 \mathrm{X}$ & Saturated & Saturated & Saturated \\
\hline $\mathrm{T}\left({ }^{\circ} \mathrm{C}\right)$ & 25 & 50 & 100 & 25 & 50 & 100 \\
\hline $\mathrm{NaCl}^{(\mathrm{wt} . \%)}$ & 1.2 & 1.2 & 1.2 & 1.2 & 1.2 & 1.2 \\
\hline $\mathrm{FeCl}_{3}$ (wt.\%) & 1 & 1 & 1 & 10 & 10 & 10 \\
\hline $\mathrm{pH}$ (crevicc or pit) & 1.92 & 1.92 & 1.92 & 0.7 & 0.7 & 0.7 \\
\hline Percentile (\%) & microns/yr & microns/yr & microns/yr & microns/yr & microns/yr & microns/yr \\
\hline 1 & $8.75 \times 10^{-5}$ & $1.87 \times 10^{-4}$ & $1.88 \times 10^{-3}$ & 0.06 & 0.26 & 2.57 \\
\hline 5 & $2.76 \times 10^{-4}$ & $5.89 \times 10^{-4}$ & $5.92 \times 10^{-3}$ & 0.19 & 0.81 & 8.11 \\
\hline 50 & $3.58 \times 10^{-3}$ & $7.67 \times 10^{-3}$ & $7.70 \times 10^{-2}$ & 2.48 & 10.50 & 105.44 \\
\hline 95 & $4.66 \times 10^{-2}$ & $9.97 \times 10^{-2}$ & 1.00 & 32.24 & 136.57 & 1371.66 \\
\hline 99 & $3.23 \times 10^{-1}$ & $6.90 \times 10^{-1}$ & 6.93 & 223.06 & 945.03 & 9491.35 \\
\hline
\end{tabular}

Note: correlation accurately predicts 1 year observations within the bounds of experimental measurements.

\section{Probability of Environment A, B and C.}

The following probabilities are assumed regarding Environments A, B and C: Environment A (340 $\mathrm{mV}$ vs. SHE, $\mathrm{pH} 2.5)=45 \%$; Environment B (640 mV vs. SHE, pH 2.5) $=10 \%$; Environment C (340 $\mathrm{mV}$ vs. SHE, $\mathrm{pH} 5-7)=45 \%$. As shown in Table $9 \mathrm{~b}$, an open circuit potential of $714 \mathrm{mV}$ vs. SHE has been observed with Alloy $\mathrm{C}-22$ in 3.05 wt. $\% \mathrm{FeCl}_{3}$ at $90^{\circ} \mathrm{C}$. However, it is believed that most sites will experience more milder conditions. In the opinion of this member of the EEP, the largest source of uncertainty in corrosion modeling is the unspecified (unknown) waste package environment.

\section{Recommendations}

1. Continuity of EEP. Continued involvement of members of Expert Elicitation Panel (EEP) members from outside of Yucca Mountain Program. For continuity, this member believes that the EEP should maintain involvement in conceptual model development, providing the types of guidance that has resulted from this process. This will provide the advantage of eliminating any possible time delay (and associated costs) required to educate a new EEP on issues specifically related to repository design and construction.

2. Technical Guidance. Specific expertise of members of the F.F.P should be exploited by the program to enhance experimental and predictive strategies.

Guidance on Stress Corrosion Cracking. Dr. Andresen should be heavily involved in planning activities regarding stress corrosion cracking of both the CAM and CRM. Dr. Andresen in an international authority on the subject and has developed predictive capability in this technical area that is now relied upon by the nuclear power industry. Preliminary estimates by Dr. JiaSong Huang indicate that a pre-existing flaw of 1.2-1.4 cm near a weld might give rise to SCC [Jia-Song Huang, "Stress Corrosion Cracking in Canistered Waste Package Containers: Welds and Base Metals" and "Thermal Embrittlement of Carbon Steels in Canistered Disposal Containers," in Memorandum entitled "Stress Corrosion Cracking and Thermal Embrittlement in Waste Packages," Lawrence Livermore National Laboratory, Memorandum, September 25, 
1997, 9 pages]. The possibility of having such a flaw and the impact on container life should be further investigated. A wide variety of valuable SCC tests are now being conducted at LLNL by Dr. Ajit Roy. These tests employ a variety of experimental techniques, including slow strain rate testing. Other techniques, such as the reverse-dc approach used by General Electric may also be of value for measuring crack propagation rates at low stress intensity. LLNL has a custom instrument that was obtained from General Electric for making such measurements. The possibility of employing this instrument at LLNL or at another designated facility should be explored in collaboration with Drs. Andresen and Roy. The possibility of using acoustic emission with guard sensors should be explored again, as it was by this EEP member during the late 1980 's.

Pitting and Localized Corrosion. The expertise of Prof. Scully and his unique experimental capability for elucidating pit initiation and propagation phenomena should be exploited to support the development of mechanistic pitting models (models based upon stochastic probability theory) capable of accurate quantitative predictions. The proper dependence of rate expressions on temperature, potential, $\mathrm{pH}$, and anion concentration must be established. Parameters must then be quantified. Specific rates of interest include those for: birth and death of embryos; embryo conversion to stable pits; penetration; and stifling (or a verifiable quantitative criterion). Techniques such as electrochemical noise analysis need to be implemented, along with microscopic evaluation. Both the CAM and CRM should be investigated.

3. Passive Film Stability on CRM. Detailed studies of the passive film formed on Alloy C-22 should be performed, establishing stability in various environments. This very thin film (tens of Angstroms) is key to waste package survival and requires atomic resolution for imaging defects. The STM provides a picture of the atomic arrangement of a surface by sensing corrugations in the electron density of the surface that arise from the positions of surface atoms ["Scanning Tunneling Microscopy: Opening a New Era of Materials Engineering," Science and Technology Review, Lawrence Livermore National Laboratory, August, 1995, pp. 4-11]. A finely sharpened tungsten wire (or tip) is first positioned within 20 Angstroms of the specimen by a piezoelectric transducer, a ceramic positioning device that expands or contracts in response to a change in applied voltage. This arrangement enables us to control the motion of the tip with subnanometer precision. $\Lambda t$ this small separation, as explained by the principles of quantum mechanics, electrons tunnel through the gap, the region of vacuum between the tip and the sample. If a small voltage (bias) is applied between the tip and the sample, then a net current of electrons (the tunneling current) flows through the vacuum gap in the direction of the bias. For a suitably sharpened tip, one that terminates ideally in a single atom, the funneling current is confined laterally to a radius of a few tenths of a nanometer. The remarkable spatial resolution of the STM derives from this lateral confinement of the current. Next, additional piezoelectric transducers are used to raster the tip across a small region of the sample. As the tip scans the surface, corrugations in the electron density at the surface of the sample cause corresponding variation in the tunneling current. By detecting the very fine changes in tunneling current as the tip is swept across the surface, we can derive a twodimensional map of the corrugations in electron density at the surface [J. Golovchenko, "The Tunneling Microscope: A New Look at the Atomic World," Science, Vol. 232, 1986, p. 48]. Potentials below and above the critical pitting potential should be explored. It is believed that such studies will enable investigators to establish the critical pitting potential and threshold chloride concentration with a higher degree of confidence than possible with cyclic polarization $[R$. D. McCright, J. C. Farmer, D. L. Fleming, "An Electrochemical Approach to Predicting Corrosion Performance of Container Materials," Proceedings of the 2nd Annual International High-Level 
Radioactive Waste Management Conference and Exposition, Las Vegas, NV, Apr. 28 - May 3, 1991, American Nuclear Society and American Society of Civil Engineers, Vol. 2, 1991, pp. 940-944]. More specifically, anion adsorption and pit initiation can be observed with atomic resolution in real time. In addition to observing pit embryos formed from halide nuclei, the STM probe could also be used to induce pits. Subsequently, the process of repassivation (healing of the passive film) can be investigated. Defects in the passive film believed to be pit embryos will be imaged. After exposure, the samples should be rinsed, dried and transferred to UHV for further inspection with both STM and complimentary techniques. A unique capability has been developed at LLNL which includes STM, low-energy electron diffraction (LEED), and other surfacc diagnostics in an ultra-high vacuum (UHV) chamber. The LEED capability enables determination of long-range order, while the STM provides information about short-range order. This combination of surface diagnostics has been used to study the structural development of thin films (films from one atom to several hundreds of Angstroms thick) during vapor deposition on singlecrystal substrates. For example, the deposition of molybdenum atoms on atomically clean silicon has been investigated [P. Bedrossian, "One-Dimensional Ordering at the Mo/Si Interface," Surface Science, Vol. 320, 1994, p. 247; "Nucleation and Ordering of $\mathrm{MoSi}_{2}$ on $\mathrm{Si}(100)$," Surface Science, Vol. 322, 1995, p. 73]. Transmission electron microscopy (TEM) can also be employed to study cross-sections of atomically thin films, as has been done with multilayer semiconductor films deposited by magnetron sputtering [J. C. Farmer et al., "Sputter Deposition of Multilayer Thermoelectric Films: An Approach to the Fabrication of Two-Dimensional Quantum Wells," Thirteenth International Conference on Thermoelectrics, Kansas City, Missouri, August 30 to September 1, 1994, American Institute of Physics Proceedings 316, Eds. Mathiprakasam, B., Heenan, P., American Institute of Physics Press, New York, NY, 1994, pp. 217-225]. Experiments to establish the integrity of the passive film on Alloy C-22 are of crucial importance to TSPA and is essential for validation of the conceptual model discussed here.

4. Microsensors and in situ optical techniques should be employed to actually measure the localized environment inside the CAM-CRM crevice. Fiber optic microprobes (fluorescence, absorption, and inelastic Raman scattering) should be used to determine $\mathrm{pH}$, as well as the concentrations of dissolved metals and anions. Microelectrodes should be used to establish potential profiles within the crevice. Such measurements will eliminate much of the need for speculation about the crevice environment. Such sensors have already becn demonstrated at LLNL and will be applied to this important problem in the future, provided that funding is maintained. In specific regard to Alloy $\mathrm{C}-22$, it may be possible to use interferometry and other reflection techniques (ellipsometry, etc.) to quantify the very small penetration rates anticipated in crevices. For example, an artificial crevice could be formed beneath a quartz optical window, with $\mathrm{FeCl}_{3}$ additions to simulate the dissolved CAM.

5. Thin-film corrosion sensors should be fabricated and deployed in the drifts at Yucca Mountain (ESF) to continuously monitor corrosion rates of A516 Gr. 12, Alloy C-22, and other metallic alloys of interest. Such films can be deposited on piezoelectric crystals so that mass change due to corrosion can be measured. Alternatively, the resistance through a sputtered thin film of the material can also be monitored. Such atmospheric corrosion studies are now being conducted at LLNL to study the impact of various gas-phase impurities on the tarnish rate of unprotected metallic mirrors in the National Ignition Facility. Phase stability could be studied with sputtered multilayers (well defined, calibrated microstructure).

6. Process-level (mechanistic) models for pilting and crevice corrosion should be further developed and improved so that experimental data can be used for reliable predictions on the repository time 
frame. The CAM-CRM crevice transport model should be enhanced to include: (a) localized concentration- and temperature-dependent solution conductivity; (b) terms to account for electromigration at low ionic strengths; (b) equations to account for sulfate, nitrate, carbonate, and other anions; (c) an appropritate activity coefficient model; (d) improved computationally-efficient model of solution equilibria, including proper hydrolysis equilibrium constants; (e) ability to deal with variable width crevice; (f) ability to account for localized breakdown of the passive film within the crevice; and $(\mathrm{g})$ a rigorous criterion for cessation of localized attack. Improvements are also needed in the stochastic pitting model, as previously discussed. These specific comments reflect noted recommendations of Prof. Joseph Payer [Case Western Reserve University], Prof. Denny Jones [University of Nevada, Reno], Dr. Narsi Sridar [Center forNuclear Waste Regulatory Analysis, San Antonio], Dr. Kevin McCoy [Framatome Cogema Fuels, Las Vegas], and others.

7. A full-time professional statistician with a background in physics, chemistry and engineering is need to be involved in the continuous evaluation and correlation of the large volumes of data now being generated by the Long Term Corrosion Test Facility at LLNL. The correlation presented in this elicitation report is viewed as a starting point, and requires continuous improvement and updating. More appropriate, non-linear functional forms should be explored. Such functional forms will enable TSPA to interpret coefficients as activation energies, orders of reaction, and related kinetic parameters. Modification of the existing test matrix should be considered. By adding additional test conditions as needed (tanks), it may be possible to achieve the advantages of a factorial design. Members of the EEP should be updated on revisions in correlations.

8. All cyclic polarization measurements should be accompanied by microscopic photographs, and perhaps even images generated by a scanning electron microscope (SEM), to substantiate the absence of localized corrosion below threshold potentials (repassivation potential, etc.). This approach has been successfully employed with great success by Dr. Gustavo Cragnolino [G. A. Cragnolino, DOE/NRC Appendix 7 Meeting, Livermore, CA, February, 1998], and should be emulated by LLNL. As recommended by Dr. Andresen, all electrochemical potential measurements should be presented with a conversion to the standard hydrogen electrode (SHE) scale to facilitate comparison with the Pourbaix diagram and other data sources.

9. It is believed that uncertainty regarding the waste package environment is the largest source of uncertainty on corrosion modeling. Significant effort must be expended by the entire program to reduce this uncertainty, and to provide those involved in TSPA and materials testing with wellspecified anticipated environments. 


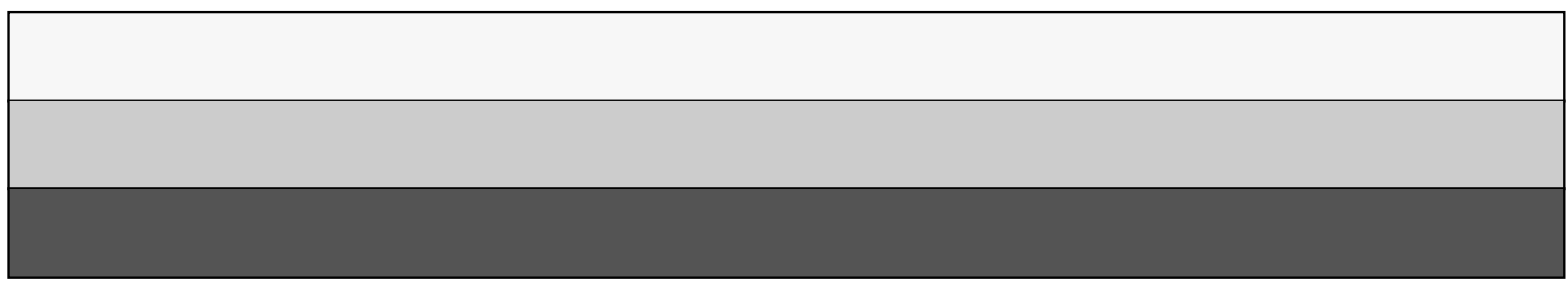

